\title{
Ks. Seweryn Wedykowski (1755-1839) i jego krytyka tlumaczenia Eneidy Franciszka Ksawerego Dmochowskiego
}

Jacek Wójcicki 


\title{
Jacek Wójcicki
}

\section{Ks. Seweryn Wedykowski (1755-1839) i jego krytyka tłumaczenia Eneidy Franciszka Ksawerego Dmochowskiego}

\begin{abstract}
Tak to jest z poezją? Bukolicy antyczni i ich nowożytni naśladowcy przyzwyczaili nas do braterskich agonów, podczas których rywale - czy będą to Dafnis i Damojtas, czy znów Mopsos i Menalkas - obdarowują się wzajem za piękny śpiew. Dotychczasowi wlaściciele chętnie wówczas przekazują w godniejsze ręce "tajstrę szychem wyszywaną” i „maczugę woskiem napuszczana" (jak Tyrsis Morsonowi u Szymonowica) ${ }^{1}$. Lecz zarazem tyle przecież i w owych sielankach zawiści i złośliwości, ciętych przytyków i ledwie nie rękoczynów jakby na potwierdzenie sentencji Czesława Miłosza o towarzyszu własnego rzemiosła:
\end{abstract}

A jednak nie znosi obok siebie innego poety,

jeśli podejrzewa, że ten jest lepszy od niego, i zazdrości mu każdej pochwały.

Gotów nie tylko zabić, ale zmiażdżyć go i zetrzeć z powierzchni ziemi².

A co z krytykami? Serdeczni to doradcy czy obmierzły „ród Zoilów”, nigdy nie widzący tego, co w utworze dobre i wielkie? ${ }^{3}$ Wszak bywa, że blask tej wielkości omija tępe oczy recenzentów, bijąc wprost $\mathrm{w}$ twarze współzawodników. Ci wówczas śpiesznie sami niosą

\footnotetext{
' Zob. S. Szymonowic, Sielanka wtóra. Wesele, w: idem, Sielanki i pozostale wiersze polskie, opr. J. Pelc, Wroclaw 2000 (BN I 182), s. 14 (w. 33-34; tajstra - sakwa, torba).

2 Cz. Miłosz, Sprawozdanie, w: idem, Na brzegu rzeki, Kraków 1994, s. 6.

${ }^{3}$ Zob. T. Mikulski, Ród Zoilów. Rzecz z dziejów staropolskiej krytyki literackiej, Kraków 1933; przedr. w: idem, Rzeczy staropolskie, Wroclaw 1964 (Studia Staropolskie, t. 14).
} 


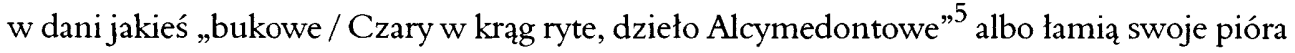
kończąc agon...

Impulsem do podobnych roztrząsań mogą być dzieje recepcji poezji antycznej w litera. turze polskiej na przełomie XVIII i XIX wieku. Zdarzyło się bowiem kilkakrotnie, ż $\mathrm{w}$ dyscyplinie arcydzieł greckich i łacińskich rozegral się pojedynek, którego triumfator: obwoływal przeciwnik nieraz długo przed finałem.

Tak oto jezuita Ignacy Nagurczewski, ów „owiec Maronowych z Nagurek dozorca”, jał nazywa go Adam Naruszewicz ${ }^{6}$, przetłumaczywszy osiemnaście lub dziewiętnaście ksią̧ Iliady „z oryginalu greckiego” (co podkreśla autor pośmiertnego elogium), porównał swó. przekład „z wychodzącym podówczas spod prasy Dmochowskiego dziełem”, po czym

...nie zazdrością, ale pociechą uniesiony zaprzestał pracy, i pierwszy zwyciężcą ogłosiwszy Dmochowskiego, powinszowal i krajowi tłumacza, i tłumaczowi dzieła $^{7}$.

Co oznacza w powyższej wypowiedzi „podówczas”? Pierwsza księga przekładu Franciszka Ksawerego Dmochowskiego pojawiła się w roku 1790, tom pierwszy, zawierając) księgi 1-8, rok później, a calość w trzech tomach opublikowana została w Warszawie w latack. 1800-1801. Tak czy inaczej, nawet najwcześniejsza reakcja Nagurczewskiego byłaby decyzja twórcy dalekiego od młodzieńczej zapalczywości, zbliżającego się do wieku lat siedemdziesięciu ${ }^{8}$, więc pobudki przedstawione przez Koźmiana można uznać z punktu widzenia psychologii za prawdopodobne. Dmochowski znał zresztą przekładowe dokonania Nagurczewskiego. W rozprawce O ttumaczach i ttumaczeniach Homera „za pozwoleniem” zainteresowanego przytoczył w calości III i IV księgę, chcąc sprawić tym „niemałe ukontentowanie publiczności" ${ }^{9}$. Dodajmy: ocalił w ten sposób dla naszych czasów choć część pracy szlachetnego starszego kolegi-tlumacza, aczkolwiek współczesny znawca przedmiotu konstatuje:

\footnotetext{
${ }^{5}$ P. Vergilius Maro, Bucolica albo pasterki... przektadania Ignacego Nagurczewskiego... - Ekloga trzecia. Palemon, w: Sielanki polskie z różnych autorów zebrane..., Warszawa, Mich. Gröll, 1778, s. 426 (w. 39-40).

${ }^{6}$ W sielance Oczekiwanie pasterza na towarzyszów, w. 209; pierwodruk: „Zabawy Przyjemne i Pożyteczne” 1771, t. 3, cz. 1, s. 113-128, potem m.in. w: Sielanki polskie..., s. 499-506. Pierwodruk Pasterek w przekladzie Nagurczewskiego: P. Wirgilijısza Marona ksiegi wszystkie..., wyd. J. A. Załuski, Warszawa, K. B. Nicolai, 1754. ${ }^{7}$ K. Koźmian, Mowa o życiu i pismach Ignacego Nagurczewskiego [wygtoszona 30 IV 1811 na posiedzeniu publicznym TPN], „Roczniki Towarzystwa Warszawskiego Przyjaciól Nauk”, t. 9, Warszawa 1816, s. 243. Koźmian pisze o pracy nad Iliadą swojego poprzednika w TPN: „do 20 pieśni doprowadziwszy”, co oznacza najpewniej liczebnik porządkowy „do dwudziestej”, a więc skompletowane pieśni dziewiętnaście. Dmochowski (zob. niżej) wspomina o osiemnastu księgach poematu.

${ }^{8}$ Urodził się 12 III 1725, zmarł w lutym 1811 roku - zob. Polski stownik biograficzny, t. 22, Wroclaw 1977, s. 455-456 (aut. hasła: K. Mrozowska). Koźmian, a za nim m.in. Feliks Bentkowski (Historia literatury polskiej wystawiona w spisie dziet drukiem ogtoszonych..., t. 1, Warszawa-Wilno 1814, s. 451), podaje błędną datę narodzin Nagurczewskiego: 1719.

${ }^{9}$ Iliada Homera przektadania Franciszka Dmochowskiego, t. 3, Warszawa 1801, s. 80; thumaczenie Nagurczewskiego: s. 80-94 (ks. III), 94-109 (ks. IV). Na s. 109-131 Dmochowski zamieszcza ks. I w przekładzie Jacka Idziego Przybylskiego, wcześniej zaś (s. 65-79) Monomachiję Parysowa z Menelatsem Jana Kochanowskiego (czyli przekład ks. III).
} 
Porównując oba te przekłady, należy stwierdzić, że rację miał raczej Nagurczewski rezygnując, niż Dmochowski chwaląc ${ }^{10}$.

Podobne zdanie o Nagurczewskiego wersjach Demostenesa, Cycerona, Wergiliusza i Homera sformułował już Stanisław Kostka Potocki, wyrocznia klasycystycznej krytyki:

Więcej on w tych pracach znajomości dawnych języków niż dobrego smaku w własnym okazal ${ }^{11}$.

Inny trochę „turniej” miał miejsce w czasach Królestwa Kongresowego między tłumaczami Bukolik Wergiliusza: Józefem Lipińskim i Kajetanem Koźmianem. Przyszły autor Ziemiaństwa polskiego zaniechał opracowywania edytorskiego gotowych już dziesięciu eklog, jak wspomina, z braku czasu i z „obawy zrobienia nieprzyjemności” Lipińskiemu (którego przekład wyszedł drukiem w roku 1805); pracę nad nimi porzucił ostatecznie w latach trzydziestych XIX wieku ${ }^{12}$.

Wreszcie przed Eneidą Marona w polskiej szacie ofiarę ze swych prób translatorskich złożył główny bohater niniejszego szkicu, nieznany dziś szerzej pedagog Seweryn Wedykowski.

W późnym oświeceniu Eneidę tłumaczono chętnie, chociaż zazwyczaj wyrywkowo większość publikacji i zachowanych rękopisów to fragmenty, rzadziej - pojedyncze księgi ${ }^{13}$. Wiele miejsca przekłady „ułomków” i „wyjątków” z eposu zajmują w czasopismach, zwłaszcza wileńskich ${ }^{14}$. Pierwszy kompletny przekład całości dzieła ukazał się w roku 1811, ale

${ }^{10}$ A. Jankowski, O polskich przekladach „Iliady”, „Meander”, R. 47, 1992, nr 5-6, s. 263.

" S. K. Potocki, Rozprawy o jezyku wymowie i literaturze polskicj - Rozprawa VIII, w: idem, Pochwaty, mowy i rozprawy, t. 2, Warszawa 1816, s. 588.

12 Zob. K. Koźmian, Pamiętriki, opr. M. Kaczmarek i K. Pecold, przed. A. Kopacz, wst. i koment. J. Willaume, Wrocław 1972, t. 2, s. 333-334; J. Wójcicki, Adan Kazimierz Czartoryski recenzentem przekładu Wergiliusza, „Meander”, R. 45, 1990, nr 4-6, s. 213-224; idem, „Pastoralna” $i$ „Eroica” Kajetana Koźmiana, w: Wergiliusz, Bukoliki, tł. K. Koźmian, wyd. J. Wójcicki, Warszawa 1998, s. 19-21.

${ }^{13}$ Zob. studium monograficzne: J. Wikarjak, Polskie przeklady „Eneidy”, „Symbolae Philologorum Posnaniensium”, t. 3, Poznań 1977, s. 91-173. Autor pomija zarówno humorystyczne trawestacje w stylu Aloisa Blumauera, jak i rękopisy z racji „przypadkowych i niepełnych” informacji o nich (s. 108). Niemniej wśród "pewnych i calościowych” prac należy wspomnieć prozaiczne tłumaczenie $11 \mathrm{ksiag}$ Alojzego Osińskiego z ok. 1809-1824, powstale w Krzemieńcu, zachowane w kilku odpisach w Kijowie i Lwowie. Zob.: K. Kolbuszewski, Ks. Alojzy Osiniski jako thumacz „Eneidy” (notatka bibliograficzna), w: Ksiega Wergilituszowa..., red. J. Rybicki, Wilno 1930, s. 167-172; E. Rabowicz, Polonica osivieceniowe w bibliotekach i archiwach ZSRR, „Archiwum Literackie", t. 5: Miscellanea z doby' Oświecenia, Wrocław 1960, s. 568 i 577; E. Woroniecki, Alojzy Osiniski. Materiaty biograficzne i spuścizna rękopiśmienna, mps Biblioteki IBL PAN w Warszawie, sygn. 173, s. 68. Kolbuszewski (s. 169) przypuszcza, że na drodze do ukończenia przekładu (zachowal się w rękopisie przygotowany tytul: „Księga XII”) stanąć mogła interesująca nas tu przyczyna „agoniczna” - ukazanie się przekładu Jacka Idziego Przybylskiego (Kraków 1811) lub też przeniesienie się autora z Krzemieńca do Wilna.

Autor monografii nie omawia powstałego podczas II wojny światowej, przygotowanego do druku w maszynopisie przekładu Eneidy krakowskiego filologa Seweryna Hammera (1883-1955) - Archiwum PAN, Oddział w Krakowie, sygn. K III-3, cz. 2, nr 3-4 (tłumaczenie heksametrem nierymowanym).

Z thumaczeń drukowanych Wikarjak, jak wcześniej Wiktor Hahn (Bibliographia Vergiliana Polonorum, „Eos”, R. 33, 1930-1931, s. 203-240), pomija II księgę poematu w przekładzie Pawła Czajkowskiego („Mrówka Poznańska" 1821, nr 7, s. 61-69; nr 8, s. 157-165; nr 9, s. 274-278; nr 10, s. 62-68).

it Zob. B. Smuszkinówna, Wergiliusz w czasopismach wileńskich pienvszej polowy XIX w., w: Ksiega Wergiliuszowa..., s. 193-215. 
po blisko ćwierćwiekowym polerowaniu. Jego autorem był kontrowersyjny filolog krakowsk Jacek Idzi Przybylski (postać godna niewątpliwie poważnej monografii, nie zdominowane - jak wiele dotychczasowych omówien - przez roztrząsanie językowych osobliwości jeg، późnych prac) ${ }^{15}$. Drugie pełne tłumaczenie, Franciszka Wężyka, gotowe było w roku 182: (zaczęte w 1804), lecz ponoć z przyczyn ambicjonalnych autor wycofał z drukarni zaakcep. towany już przez cenzurę egzemplarz dzieła, opublikowanego dopiero pośmiertni w 1878 roku $^{16}$. (Opus posthumum stanowilo też wydane w 1809 roku tlumaczenie Dmochow. skiego, uzupełnione przez wydawców o trzy ostatnie księgi) ${ }^{17}$.

Jednak żadna polska wersja poematu nie wzbudziła wówczas tyle zainteresowania, ik otaczało przekład, którego w istocie nigdy nie było..., czyli tłumaczenie Marcina Molskiego

Molski, słynny wierszopis, któremu współcześni przyznawali wręcz „palmę poezji epicz. nej" ${ }^{18}$, łączył w sobie nieprzeciętną łatwość rymowania z obrotnością i brakiem skrupułów Utworami okolicznościowymi niezmordowanie obdarzał rozmaitych możnych tego świata Wielekroć cytowany i przeksztalcany wierszyk powiadał:

Idzie Molski, w ręku oda

Dla Chrystusa, dla Heroda,

A w kieszeni wierszów trzysta

Dla przyszłego Antychrysta.

Czynił to z zadziwiającą częstotliwością; „jakoż z jego pism można by kalendarz ułożyć' - stwierdza Kajetan Koźmian ${ }^{19}$.

W marcu 1801 roku Molski opublikował piętnastostronicową broszurkę Ogłoszenie dzieł pod tytutem „Eneida” Wirgiliusza, gdzie potencjalnych a zdecydowanych („Czas prenumerat)

\footnotetext{
${ }^{15}$ Zob. J. Wikarjak, op. cit., s. 93, 114-115, 133-135; A. Jankowski, op. cit., s. 257-260. Ostatnio Przybylskiemu poświęcona została znaczna część ważnej dla niniejszych rozważań pracy Jerzego Snopka Provincj، oświecona. Kultura literacka Ziemi Krakowskiej w dobie Oświecenia 1750-1815, Warszawa 1992. Tenże jest autoren zwięzłej sylwetki Przybylskiego w: Pisarze polskiego oświecenia, red. T. Kostkiewiczowa, Z. Goliński, t. 2 Warszawa 1994, s. 207-229.

${ }^{16}$ Zob. J. Wikarjak, op. cit., s. 98, 118, 126-127, 136-137; Z. Goliński, Papiery Franciszka Wężyka w rękopisact ossoliniskich, „Ze Skarbca Kultury” 1953, z. 1, s. 54. Badacz cytuje odpowiedzialnego za subskrypcję krakow. skiego księgarza Ambrożego Grabowskiego (Wspomnienia, t. 2, Kraków 1909, s. 147 [nie 146]), którego Wężyk powiadomit pewnego razu: „Kiedym wczoraj na wieczornym zebraniu w domu JW. Prezesa Senatu przypatrzył się żebraninie, $z$ jaką gospodyni domu zachęcała obecnych, aby przyjęli bilety prenumeracyjne na jakie؛ pismo, odeszła mię chęć od puszczania na prenumeratę Eneidy i proszę wstrzymać rozdawanie prospektów" ${ }_{17}$ Zob. J. Wikarjak, op. cit., s. 98. Dodajmy, że księgarz wileński Józef Zawadzki starał się w tym czasiє pozyskać wlasnych, konkurencyjnych tlumaczy Wergiliusza, czego świadectwem jest listowna odpowiedź doktora filozofii Józefa Łomanowicza z Mozyrza (22 VI 1806), gdzie korespondent, mając gotowy brulion przekładu połowy Eneidy, proponuje termin dwóch lat na dokończenie całości; zob. Materiaty do dziejóu literatury i osiviaty $z$ archiwum drukarni i ksiegarni Józefa Zawadzkiego w Wilnie, t. 1: Czasy Uniwersytetu Wileniskiegc po rozbiorach (do roku 1841), opr. T. Turkowski, Wilno 1935, s. 168.

${ }^{18}$ Zob. K. Koźmian, Pamiętniki, t. 3, s. 398.

${ }^{19}$ W liście z 20 IX 1855 - zob. Korespondencja literacka Kajetana Koźmiana z Franciszkiem Wẹżłkiem (1845-1856), opr. S. Tomkowicz, „Archiwum do Dziejów Literatury i Oświaty w Polsce”, t. 14, Kraków 1914 , s. 241.
} 
rozciąga się tylko do pól roku” - s. 15) subskrybentów dzieła wyjątkowej podobno urody („Edycja jego będzie w dwóch lub trzech tomach, na holenderskim papierze, ozdobiona twarzą Wirgiliusza z paryskiego sztychu wziętą...” - tamże) znęcić miały przetlumaczone fragmenty z kilku ksiąg (10 wersów księgi I, 64 wersy księgi II, 85 wierszy z księgi IV i $64 \mathrm{z}$ księgi VI). Ale i niecałe ćwierć tysiąca - przeciętnych poetycko - linijek wystarczyło, by opromienionego rozgłosem twórcę okrzyknięto genialnym następcą Marona.

Literackie sławy nie szczędziły pochwał. Dysponujemy dziś ledwie garstką listów do Molskiego, lecz popatrzmy - oto Franciszek Dmochowski zachęca:

Trwaj tylko WPan Dobr. w przedsięwzięciu i zbogać literaturę polską najpiękniejszym dziełem,

Filip Nereusz Golański rewanżuje się komplementami i — biletami subskrypcji swojego przekładu Plutarcha, a schorowany Grzegorz Piramowicz wprawdzie odżegnuje się od udzielania merytorycznej pomocy, ale słów uznania nie skąpi i wróży nowej Encidzie powodzenie $^{20}$. Recenzowania, a tym samym i stymulowania powstającego dzieła podjął się za to najwyższy z możliwych autorytetów:

Stanisław Potocki mówił mi, iż jeśli pozwolisz, będzie w manuskrypcie czytał twego Wergiliusza i dawać ci będzie swoje uwagi -

— komunikuje Molskiemu Tadeusz $\mathrm{Czacki}^{21}$, jeszcze w następnym roku przypominający serdecznie o zobowiązaniu:

Jak mi jest miło, że każdy tobie oddaje palmę, każdy cię godnym zrobienia przekładu Wirgila nazywa 22 .

Czy doszło do recenzowania - nie wiemy, w kazdym razie chef d'oeture in spe długo nie opuszcza myśli Potockiego, zrazu życzliwego:

...piękne jej [Eneidy - JW] ułamki są w ręku publiczności i dają wcześnie taką zaletę całkowitości dzieła, że się o dokładności jego wątpić nie godzi ${ }^{23}$,

później nerwowego:

Przyrzekł on tlumaczenie Eneidy, a wzory tej pracy przez niego wydane czynią, że niecierpliwie publiczność oczekuje uiszczenia się jego w danym sobie słowie ${ }^{24}$.

\footnotetext{
${ }^{20}$ Zob. Materialy do dziejów piśmiennictwa polskiego i biografii pisarzów polskich, opr. T. Wierzbowski, t. 2, Warszawa 1904, s. 149-150: bilet F. K. Dmochowskiego z 20 III 1801 (nr 209); list F. N. Golańskiego z 25 V 1801 (nr 210); list G. Piramowicza z 10 VI 1801 (nr 211).

21 Ibidem, s. 152; list bez daty z 1801 (nr 213/1).

22 Ibidem, s. 154; list z 23 IV 1802 (nr 213/3).

${ }^{23}$ S. K. Potocki, bruliony pochwal pisarzy dla TPN z 1801 roku - Archiwum Główne Akt Dawnych w Warszawie (AGAD), Archiwum Publiczne Potockich, rps ApP 233, s. 298.

2+ Idem, Rozprawy o jezyku..., s. 589.
} 
Nie brakowało i zachęt subtelnych. Oto w „podróży sentymentalnej” po Włoszecl dziedzic Dzikowa, hrabia Jan Feliks Tarnowski, wraz z artystycznie uzdolnioną żoną, Waleri: ze Strojnowskich, przybywa w 1804 roku do Neapolu i Posilippo, gdzie znajduje się licznit odwiedzany „grób Wergiliusza”. Jak przystało na piewcę ziemiańskiego trudu,

Ce monument (...) se trouve enclavé dans le jardin d'un bon paysan, qui nous en a fait les honneurs ${ }^{25}$.

Małżonkowie zrywają tam dwie gałązki laurowe. Jedna ma zostać ich własną pamiątką druga zaś przeznaczona jest dla właśnie dla Molskiego, pod istotnym wszakże warunkiem:

Si toutefois il achève jamais sa belle mais interminable traduction de „l'Enêide"26.

W charakterze dygresji przyznać trzeba, że państwo Tarnowscy nie byli w swych symbolicznych gestach oryginalni. Cienisty „Grób Wergiliusza” oskubywali miłośnicy literatury zє wszystkich stron, w tym także z Polski, klasycy i sentymentaliści. Zachowała się akwarela przedstawiająca ów zakątek, oraz gałązka laurowa stamtąd, zerwana w 1791 roku podczas podróży włoskiej — ostatniego, jak się okazało, wytchnienia przed mającymi nadejść wydarzeniami burzliwymi i ponurymi - prymasa Michała Poniatowskiego, ofiarowana Adamow: Naruszewiczowi ${ }^{27}$. Ze strony „sentymentalnych” zaś stosowną gałąź uszczknęła Izabela Czartoryska, przesyłając ją do Paryża ówczesnemu żywemu Wergilemu, za jakiego uchodził w Europie Jacques Delille, thumacz Georgików i autor Ogrodów.

Znajomość Wergiliusza zawdzięczała mu również madame Tarnowska, co kwituje we wcześniejszym fragmencie dziennika podróży, poświęconym rodzinnej Mantui rzymskiegc wieszcza. Przy popiersiu poety Tarnowska „z głębi serca” składała dzięki Delille’owi za jegc przekład i doskonałe oddanie starożytnego wzoru ${ }^{28}$.

${ }^{25}$ W. Tarnowska, Journal du voyage en Italie... (1803-1804), publ. par G. Mycielski, „Revue de Pologne”, R. 2 1924-1925, nr 2, s. 488 („Pomnik ten [...] znajduje się w zamkniętym ogrodzie pewnego poczciwegc wieśniaka, który nas wpuścił”; notatka z 7 I 1804).

${ }^{26}$ Ibidem, przyp. aut. 2 ("Jeśli ten wreszcie uskuteczni swój piękny, acz nieukończony przekład Eneidy”).

${ }^{27}$ Zob. B. Biliński, I viaggiatori illıministi e romantici polacchi pellegrini sulla tomba di Virgilio a Napoli, w: Atti del convegno italo-polacco „Viaggio in Italia e viaggio in Polonia”..., a cura di D. Quirini-Poplawska, Kraków 1994 (Zeszyty Naukowe UJ 1128), s. 206-207; gałązka w zbiorach muzealnych Biblioteki Kórnickiej, sygn. M. K. 3458.

${ }^{28}$ Zob. W. Tarnowska, op. cit., „Revue de Pologne”, R. 2, 1924-1925, nr 1, s. 53 (notatka z 22 XI 1803). Omówienie dziela m.in. w: J. Mycielski, Podróż Polki do Whoch w epoce napoleońskiej, 1803-1804, „Przegląd Polski”, R. 31, 1897, t. 123 zesz. 367, s. 69-103 (o grobie Wergiliusza s. 81); S. Wasylewski, Podróże i malatury pani Tarnowskiej, w: idem, Tivarz i kobieta, Kraków 1960, s. 107-120 (o grobie Wergiliusza s. 114-115); A. Żyga, Dzików w kreggu pseldoklasyków, „Prace Humanistyczne Rzeszowskiego Towarzystwa Przyjaciół Nauk” 1975, s. 63-100; V. Tarnowska, Mes voyages (1804), deuxième partie, éd. et annot. par M. Wilczyńska, „Biuletyn Biblioteki Jagiellońskiej”, R. 39, 1989, nr 1-2, s. 35-75 (tu szczególy bibliograficzne poprzednich części dziennika, wydanych przez prawnuka autorki). 
Gałązka z Neapolu żyła w pismach Delille’a własnym życiem. W jednym z wydań znajduje się anonimowy wiersz, skierowany do francuskiego poety, osnuty na znajomym „roślinnym" motywie:

Aux champs de Parthénope, en vous lisant, Delille, $J$ 'ai porté mon hommage aux restes de Virgile... ${ }^{29}$.

Obszerny utwór jest reprezentatywny dla postawy wielbicieli paryskiego starca, którego z kolei reakcję oddaje nie mniejszych rozmiarów poemat $A M$. de $C^{\star \star \star}$, Polonais, a więc rewanż Izabeli Czartoryskiej ${ }^{30}$. Wzniosła i nieco przewidywalna deklamacja nad gałązką, nazywaną z emfazą „objet sacré”, nie wyczerpuje jednak „poezjotwórczej” roli Maronowego lauru. Oto bowiem w niezwykle pochlebczym wierszu do cara Aleksandra, towarzyszącym przekładowi Eneidy, tłumacz odkrywa, czym tak naprawdę były dlań owe nadsyłane mu „fraszki” i listki:

...Je vous offre aujourd'hui le laurier de Virgile;

Non ce laurier profane et mensonger

Que sur le Pausilyppe au crédule étranger

L'intérêt vend, et que l'erreur achète $(. . .)^{31}$.

Myśl o istotnym „wieńcu”, jakim jest poezja w odróżnieniu od „przyziemnych i złudnych" pamiątek, to oczywiście stary motyw literacki. A jednak przykro usłyszeć, że było się „naiwną cudzoziemką" w kleszczach wyrachowanych handlarzy...

Nie wiemy, czym odwdzięczyl się Molski pani Tarnowskiej, bo nie było za co, jeśli podróżniczka utrzymała w mocy warunek wręczenia pamiątki spod Wezuwiusza. Oczekiwane dzieło nie wschodziło. Tłumacz nie spieszył się jednak, ponieważ, uprzedziwszy lojalnie w prospekcie (s. 15), iż „Prenumerata na to dzieło kosztuje czerwonych zlotych dwa”, zebrał zapewne wystarczającą kwotę, by całą intrygą (nie mówiąc o wawrzynowych gatązkach) nie zaprzątać sobie więcej głowy.

Potomek i wydawca jego pism stara się usprawiedliwić opieszałego przodka:

Wiekiem zaś i trudami ociężal, liczył bowiem wtedy pięćdziesiąt lat życia i do mozolnej pracy nie nawykł. Powołaniem też jego rzeczywiście nie było studiowanie rzymskiego poety niełatwe i thumaczenie wierne a $z$ wdziękiem w pol-

\footnotetext{
29 A Virgile-Delille, en lui envoyant un morceau de laurier coupé sur le tombeau de Virgile, w: J. Delille, Recueil de poésies et de morceaux choisis..., Paris 1801, s. [5]-6.

${ }^{30}$ Zob. np. wyd.: idem, Oetures, t. 1: Poésies fugitives..., Paris 1809, s. 231-232; idem, Oetures complètes..., Paris 1840, s. 868-869. O kontaktach księżnej z francuskim poetą zob.: A. Aleksandrowicz, Izabela Czartoryska. Polskośc i europejskość, Lublin 1998, s. 29-79: Sztuka czy natura? Jacques Delille w ogrodach pulawskich.

${ }^{31} \mathrm{~J}$. Delille, Épitre dédicatoire a S. M. Alexandre $I^{\text {rr }}$, Empereur de toutes les Russies, w: idem, Oeuvres complètes..., s. 383 (w. 22-25).
} 
skim języku, bo nie miał w tym wprawy ani cierpliwości, ale wierszyki ulotne,

które snuć umiał $z$ taką latwością, a nieraz $z$ dowcipem i humorem ${ }^{32}$.

Czytelnicy i koledzy nie byli jednak wyrozumiali ani dla tempa rzekomej „pracy”, ani dl komicznych błędów próbki talentu tłumacza. Dwakroć wycelował w Molskiego ostre piórkc Cyprian Godebski. W satyrycznym wizerunku Towarzystwa Przyjaciół Nauk pojawia sic „jegomość, co ma minę kreta”, który może być niebezpieczny i „palnąć prospekt na satyrę”

$\mathrm{Z}$ jego laski rok drugi, jak stolica nasza

Spodziewa się przybycia co dzień Eneasza,

Lecz go snać przytrzymala ta prośba Dydony:

"Jeślim ci z której dobrze usłużyła strony..."33

Autor wiersza śmieje się tu z fragmentu dramatycznej skądinąd księgi IV, który zyska największą chyba - wbrew spodziewaniu tłumacza - popularność:

Zaklinam cię na wspólne serc naszych umowy,

$\mathrm{Na} z a c z e ̨ t y$ w pieszczotach związek Hymenowy,

Jeślim ci dobrze z której usłużyła strony,

Jeśliś jaką znał rozkosz na lonie Dydony,

Proszę cię, jeśli jeszcze prośby ważyć mogą,

Wzrusz się upadkiem domu, oddal tę myśl srogą 34 .

Drugi raz Godebski przyszpilił Molskiego w wierszu Na odjazd Juliana Niemcewicza dc Ameryki z tegoż roku 1803, w serii nieprawdopodobieństw (adynata), mających zobrazować stałość afektów autora do Juliana Ursyna:

(...) I choć o tym bynajmniej nigdy nie pomyślę,

Ażeby kiedy wody przebrało się w Wiśle,

Pierwej ona swe źródła obfite wysączy,

Niż pisarz prospektowy Eneidę skończy... 35

32 W. Radliński, Marin Molski, w: M. Molski, Pisma..., t. 1, Warszawa 1855, s. XII-XIII.

${ }^{33}$ Cyt. za: A. Kraushar, Satyra na Towarzystwo Przyjaciót Nauk z roku 1803, w: idem, Echa przesztości. Szkice, wizerunki i wspomnienia historyczne, Warszawa 1917, s. 219 (w. 29-32). Wydawca ogłosił wiersz jako anonimowy: w przypisie blędnie określając postać „Z miną kreta” jako Franciszka Dmochowskiego (s. 220-221). Autorstwo Godebskiego wskazal Kazimierz Wladysław Wójcicki, zob. C. Godebski, Wybór wierszy, opr. Z. Kubikowski, Wrocław-Kraków 1956 (BN I 161), s. CXVIII (Uwagi edytorskie) i 51-58 (List do przyjaciela z Warszawy dr. 7 maja 1803 r.) - tu tekst w nieco odmiennym brzmieniu, ustalonym przez Juliusza Wiktora Gomulickiego; edytor tomu nie wspomina publikacji Kraushara.

${ }^{3+}$ M. Molski, Ogtoszenie dzieta pod tytutem „Eneida” Wirgiliusza, [Warszawa 1801], s. 9: Wypis z ksiegi IV (w. 67-72).

35 Cyt. za: A. Kraushar, Na odjazd Juliana Niemcenvicza do Ameryki (Rok 1803), „Pamiętnik Literacki”, R. 9, 1910 , s. 112-113. Wydawca anonimowego utworu przypuszcza, że autorem był Kajetan Koźmian; autorstwo Godebskiego (za wydaniem Dziet wierszem i prozq..., cz. 2, Warszawa 1821) wyjaśnia Ludwik Bernacki: Autor wiersza "Na odjazd Niemcenvicza", ibidem, s. 291. Kraushar przytacza wiersz z kopii bogatszej od druku z 1821 roku o dwuwiersz: 
Lata mijały, ale nie emocje. Jeszcze w roku 1815 przeciw Molskiemu wystąpił Antoni Gorecki, tym razem w aurze konfliktu poetyckich igraszek z patriotycznym obowiązkiem:

Dziesięć lat do Warszawy idzie twój Wirgili,

A ty chcesz, gdyby wszyscy w nadzieję wierzyli.

Oddaj ziomkom pieniądze, oddaj im w tą chwilę,

Gdzie bliznami okrytych jęczy braci tyle.

$\mathrm{Na}$ wsparcie twych kolegów lepiej ich użyją,

Oni za kraj walczyli, a dziś w nędzy żyją ${ }^{36}$.

Szczególnie mocno „kompleks Molskiego” odczuwał Kajetan Koźmian, na którego Ziemiaństwo polskie klasyczna publiczność Królestwa Kongresowego czekała zresztą w równym napięciu, co na tamtą Eneidę. Nie bacząc na absolutnie odmienną sytuację dziejową po upadku powstania, starał się już w 1832 roku o ponowny druk i rozprowadzenie swojego poematu, oddanego pod prasy puławskie - za pieniądze z prenumeraty - niemal równocześnie z „nocą listopadową”. „Wcale sobie nie życzę wyjść na Molskiego” — perswadowal Ludwikowi Osińskiemu, prosząc go o wstawiennictwo w cenzurze ${ }^{37}$.

Ale były przecież i reakcje jak ta opisana przez Czackiego we wspomnianym wcześniej liście do Molskiego z 1801 roku:

Rektor szkół lubelskich zaczął tłumaczyć Wirgila; gdy twój prospekt przeczytal, zaraz spalił.

Mowa tu właśnie o Sewerynie Wedykowskim ${ }^{38}$.

Innego typu, tym razem konstruktywny, odbiór pracy Molskiego - a raczej jej braku zanotował pijarski antologista Szymon Bielski:

Pierwej nieszczęścia Pragi czas pamiątkę zatrze,

Wprzód sufler na warszawskim ochłonie teatrze...

Wydawca tomu BN nie zna publikacji Kraushara i podaje tekst krótszy za Dzielami z 1821 roku (zob. C. Godebski, Wybór wierszy, s. 64).

${ }^{36}$ Odpowiedź autorowi kolędy na r. 1815 w Warszawic (Gorecki Molskiemu), w. 23-28, cyt. za: W. Pusz, Antoni Gorecki contra Marcin Molski, w: idem, Między Krasickim i Slowackim, Kraków 1992, s. 29 przyp. 22; w podstawie edycji (odpisie) przypis do w. 23: „Autor kolędy oglosil prenumeratę na tłumaczenie Eneidy, pobral pieniądze znaczne od prenumeratorów, a po dziś dzień nie wydaje”.

${ }^{37}$ Rps Biblioteki Jagiellońskiej 6233, k. 20 v. (list z Piotrowic, 22 II 1832). Odpowiadając, Osiński przekonywał: „Nie masz tu żadnego podobieństwa z prenumeratą Molskiego. Jemu nie zastąpił drogi Lelewel ani rewolucja; on wziął pieniądze na Wirgiliusza w prospekcie, tu zaś cała publiczność wie dobrze, że dzieło jest i jakie jest..."; rps Biblioteki PAU-PAN w Krakowie, sygn. 2031, t. 1, k. 121 v. (list z Warszawy, 10 III 1832).

$\mathrm{Na}$ marginesie dodać można, iż podobnie jak w przypadku Molskiego nieudaną a wysoko mierzącą imprezą (ale chyba niedochodową) było zapowiadane w 1817 roku prospektem przez Tadeusza Szostakowskiego tłumaczenie wszystkich pieśni i epodów Horacego; zob. W. Ogrodziński, Polskie przekłady Horacego, Kraków 1935, s. 117 [144]-118 [145].

${ }^{38}$ Zob. Materialy do dziejóu' piśmiennictwa..., s. 152 (nr 213/1); w przypisie postać „rektora” rozszyfrowana blędnie jako Kazimierz Jaworski. 
Gdy to żądane thumaczenie dotychczas na widok publiczny nie wychodzi, Fr. Dmochowski, niezmordowany w przekładaniu celniejszych poetów, na żądanie przyjaciół zajął się tą praca; wyłożył już kilka książek [ksiąg poematu JW], i zapewne ukończy z chwałą, jeśli mu zdrowie posłuży ${ }^{39}$.

Oprócz ciepłych uczuć do Wergilego, przechowanych być może jeszcze z wczesnych la pracy nauczycielskiej $\mathrm{w}$ zakonie pijarów ${ }^{40}$, wielką rolę $\mathrm{w}$ podjęciu działań translatorskick grały tu zapewne względy odpowiedzialności zawodowej. Prospekt Molskiego, rozpowszechniany w broszurze jako nadbitka, był bowiem równolegle zamieszczony w redagowanym przez Dmochowskiego „Nowym Pamiętniku Warszawskim”, i to na starcie ambitnegc czasopisma (numer marcowy z 1801 roku, s. 339-353). Początkom „Pamiętnika” patronowa: Wergiliusz-autor Eneidy także jako Palemon-rozjemca kolejnego agonu: w numerze czerwcowym Dmochowski publikuje (anonimowo) własną wersję przekleństw Dydony z IV księgi, w sierpniu zaś - początek tejże księgi pióra Stanisława Trembeckiego ${ }^{41}$. Być może redaktor pisma miał nadzieję regularniejszego otrzymywania materiału od Molskiego. a przy przedłużającym się jego milczeniu pragnąl ratować honor Wergiliański swego periodyku - dlatego też w 1805 roku opublikował w "Nowym Pamiętniku” dokonany przez siebie przekład księgi pierwszej oraz obszernych partii dwu następnych ksiąg ${ }^{42}$. Nie poprzestając na tych wyimkach, zwyczajem twórców klasycznych zwracal się o poradę do autorytetów, takich jak Jan Śniadecki (późniejszy „starzec ze szkiełkiem” z Romantyczności), który zachęcał autora Sztuki rymotwórczej do wytrwałości nad Eneidą i dodawał animuszu, krytykując świeżo wydany w Paryżu przeklad wspomnianego wcześniej Jacquesa Delille ${ }^{43}$. Niestety: w czerwcu 1808 roku niespełna pięćdziesięcioletni tłumacz zmarł, pozostawiając Eneidę tylkc $\mathrm{w}$ trzech czwartych gotowa ${ }^{44}$. Niewykończenie pracy Dmochowskiego było dla ówczesnych odbiorców i krytyków okolicznością łagodzącą sądy o dziele. Świadectwem tego jest uważana dotąd za najobszerniejszą recenzja Ludwika Osińskiego w redagowanym przezeń „Pamiętniku Warszawskim”45. Osiński, jeden z wodzów „obozu klasyków”, roztrząsnął w niej ogó-

${ }^{39}$ [S. Bielski], wstęp w: Wybór różnych gatunków poezji z rymopisów polskich dla użytku mtodzieży, cz. 2, Warszawa 1806 , s. nlb.

to "Jego pierwsi biografowie w nekrologach (...) wspominają nieznaną dziś jego «rozprawę o Eneidzie. napisaną w szkołach radomskich, a w manuskrypcie pozostałà" - S. Pietraszko, Doktryna literacka polskiego klasycyzmu, Wroclaw 1966 (Studia z Okresu Oświecenia, t. 4), s. 464; autor cytuje nekrolog Konstantegc Wolskiego, Dodatek do „Gazety Korespondenta” 1808, nr 51 (25 VI), s. 672.

${ }^{+1}$ Zob. W. Tyszkowski, „Nowy Pamiętnik Warszawski” F. K. Dmochowskiego i jego rola w popularyzowanitu wiedzy o literaturze antycznej, „Classica Wratislaviensia”, t. 11, Wrocław 1987, s. 95-96.

42 Ibidem, s. 96.

${ }^{+3}$ Zob. Korespondencja Jana Śniadeckiego. Listy z Krakowa, t. 2: 1787-1807, ze spuścizny po L. Kamykowskim opr. M. Chamcówna i S. Tync, Wrocław 1954, s. 401 (list CLXXXII do F. K. Dmochowskiego z 14 IX 1805), 409-410 (list CLXXXVII do tegoż z 27 XI 1805).

${ }^{4}$ „W następnym roku spodziewam się tom pierwszy drukować, bo mam już dzieło w większej połowie skończone" - pisał Dmochowski 8X 1805 roku do Jana Gorczyczewskiego (Korespondencja Jana Gorczyczewskiego w sprawach literackich, opr. J. T. Pokrzywniak, „Pamiętnik Literacki”, R. 74, 1983, z. 4, s. 252).

t5 Zob. „Pamiętnik Warszawski”, t. 3, 1809, nr 8 z 1 XI, s. 215-237. 
lem 20 miejsc (ale tylko z I księgi), które wzbudziły jego wątpliwości, argumentowane znaczeniem oryginału bądź harmonią polskich wyrażeń. Nie są to jednak ataki na nieżyjącego autora, raczej fachowe przestrogi dla innych „talentów zatrudniających się teraz tłumaczeniem Wirgiliusza"46.

A jaki obraz przedstawiała ówczesna krytyka literacka w ogóle? Trudno powstrzymać się od spojrzenia w „małpie zwierciadło” Mickiewicza, w którym widzimy, że...

Zdanie księdza Golańskiego przytacza Franciszek Dmochowski, Franciszka Dmochowskiego przytacza Ludwik Osiński, wszystkich przytacza Stanisław Potocki, wszyscy przytaczają Stanisława Potockiego. Zdania te koncentrują się na chwilę w Historii literatury Bentkowskiego, skąd w różnych przytaczaniach kanałem dzienników, przedmów i mów pochwalnych do swoich źródeł wracają. Utrzymuje się tym sposobem w Warszawie w ciąglym obiegu pewna liczba zdań, nie mających gdzie indziej żadnej wartości, jak na Żmudzi ciągle krążą stare talary holenderskie i orty ${ }^{47}$.

Już bez pamfletowej zaciętości dzisiejsi badacze zauważają, że dla krytyków klasycznych, wyciągających konsekwencje $z$ najszczegółowszej recepty zawartej w Liście do Pizonów ${ }^{48}$,

...proces oceny zasadza się na obserwowaniu i ulepszaniu wydzielonych fragmentów, chybionych miejsc dzieła, a nie na uchwyceniu zasad rządzących jego całością ${ }^{49}$.

Odnosi się to zarówno do twórczości oryginalnej, jak i przekładów, w których drobiazgowo śledzono przede wszystkim oznaki „gładkości” i „wierności” ${ }^{50}$. Czy jednak autorzy, porównujący się wzajem — jak niegdyś Horacy z Propercjuszem — do coraz znaczniejszych

${ }^{16}$ Ibidem, s. 219. Omówienie recenzji (wyd. też w Dziełach Osińskiego, t. 4, Warszawa 1862, s. 354-365) zob. J. T. Pokrzywniak, Thumaczenia z literatur obcych $w$ recenzjach prasowych poczatków XLX wiekt. Na przyktadzie „Nowego Pamiętnika Warszauskiego" i „Pamiętnika Warszawskiego”, „Pamiętnik Literacki”, R. 71, 1980, z. 1, s. 49-80; zob. też J. Ratyńska-Guzek, Problemy życia literackiego Warszaury w latach 1807-1814, w: Problemy kultury literackiej polskiego Ośiviecenia. Studia, red. T. Kostkiewiczowa, Wroclaw 1978, s. 159.

${ }^{47}$ A. Mickiewicz, O krytykach i recenzentach warszaluskich (1829), w: idem, Dziela, t. 5, Warszawa 1955, s. 271-272; w jednym z przypisów autor pastwi się nad sądem S. K. Potockiego o Iliadzic Dmochowskiego (s. 272): Zob. też: T. Sinko, Mickiewicz i antyk, Wrocław-Kraków 1957, s. 270-276.

${ }^{+8}$ Horat. De arte poetica 445-452; zob. A. Wójcik, Problematyka literacka w twórczości Horacego, Poznań 1978, s. 60-61.

${ }^{+9}$ T. Kostkiewiczowa, Krytyka literacka $w$ Polsce $w$ epoce oświecenia, w: E. Sarnowska-Temeriusz, T. Kostkiewiczowa, Krytyka literacka $w$ Polsce $w$ XVI $i$ XVIII wieku oraz w epoce oświecenia, Wrocław 1990, s. 157. Zob. też m.in. J. Ziętarska, O metodzie krytyki literackiej w dobie Oświecenia, Warszawa 1981; I. Kitowiczowa, O zadaniach krytyki literackiej lat 1800-1820, w: Badania nad krytyka literackq, red. J. Sławiński, Wroclaw 1974; polemika: M. Strzyżewski, Przemiany krytyki literackiej $w$ Polsce $w$ świetle wypowiedzi metakrytycznych z lat 1811-1830..., „Acta Universitatis Nicolai Copernici. Filologia Polska”, t. 37, Toruń 1992, s. 19-50.

so Zob. J. Ziętarska, Pojęcie wartości przekladu w okresie przełomu literackiego 1815-1830, w: Poetyka i stylistyka sloviańska, red. S. Skwarczyńska, Wroclaw 1973, s. 237-245; eadem, Sztuka przektadu w pogladach literackich polskiego Ośluiecenia, Wrocław 1969 (Studia z Okresu Oświecenia, t. 10), s. $92-93$ (o F. K. Dmochowskim). 
postaci $^{51}$, czego nie przemilcza w cytowanym tekście Mickiewicz ${ }^{52}$, chętnie odbierali głos! krytyczne pod swoim adresem?

Pewną orientację $\mathrm{w}$ tym zakresie daje epizod z życia przedwcześnie zgasłego Józef: Sygierta, thumacza między innymi Iliady i Eneidy, jednego $z$ największych polskich talentór filologicznych z początku XIX stulecia. Napisał on - niezwykle wysoko cenioną przez dwudziestowiecznych specjalistów - analizę Iliady w przekładzie Dmochowskiego, ale

...wolał jej nie publikować. Jak wynika z listów krakowskiego literata, jego decyzja w tej kwestii łączy się ze zjawiskiem ogólniejszym (...). Otóż twórcy przyjmowali wówczas wszelkie uwagi krytyczne, wymierzone w ich dzieło, ze złą wiarą. W krytyku widzieli wroga osobistego niemalże (...), nawet gdy ów krytyk był również pisarzem. Biada mu, kiedy był zaledwie dziennikarzem, zwykłym miłośnikiem literatury bądź bliżej nieokreślonym anonimem $!^{53}$

Musiała więc tu działać niebagatelna presja psychiczna, skoro Sygiert, bez obaw rywalizujący poetycko z przyjacielem, wspomnianym już Franciszkiem Wężykiem (z którym razem wyglądal Eneidy Molskiego), mimo zachęt samego Dmochowskiego - który planowa wznowienie poprawionej Iliady - nie zdecydowal się na upublicznienie swojej pracy ${ }^{54}$ A przecież - jeśli wierzyć zainteresowanym, ich listom i wspomnieniom - Dmochowskiemu, Molskiemu, Koźmianowi krytyka potrzebna byla niczym tlen... może należy dodać: krytyka pochlebna, choć sami deklarowali (w licznych wypowiedziach metapoetyckich) gotowość poddania się każdym wyrokom znawców.

Kłopoty z brakiem doradców w przedmiocie rozpoczętego Ziemiaństwa polskiego wspomina Koźmian, wymieniając najpierw sąsiadów, Tadeusza Kownackiego i Grzegorza Piramowicza, którzy wywędrowali wówczas — około 1801 roku — z pobliża Piotrowic w dalsze rejony kraju:

${ }^{51}$ Horat. Epist. II 2, 99-101; zob. A. Wójcik, op. cit., s. 84-88.

${ }^{52}$ Wedle Mickiewicza, ,Jak niegdyś w Paryżu nazywano Laharpa Kwintylianem francuskim, a w Warszawiє Kopczyńskiego Lomondem (dla uczczenia) -- tak Dmochowski nazywany był Laharpem, a w Wilnie Slowacki [Euzebiusz, profesor wymowy - JW] Dmochowskim" (O krytykach i recenzentach ..., s. 267).

${ }^{53}$ J. Snopek, op. cit., s. 30. W tekście obszerna charakterystyka postaci Sygierta i jego kręgu literackiego. Zob. też: idem, Nieznana karta z dziejów ośvieceniowej recepoji literatury antycznej, „Meander”, R. 38, 1983, z. 9, s. 329-336; artykułu tego nie przywołuje A. Jankowski (O polskich przektadach „Iliady"), choć Sygierta wspomina (op. cit., s. 255-256). Recenzję opublikował B. Gubrynowicz, Nieznana wspótczesna krytyka J. Sygierta przektadu „Iliady” Dmochowskiego, „Eos”, R. 32, 1929, s. 255-278.

${ }^{5+}$ Zob. J. Snopek, op. cit., s. 183 (tu cytat z listu Wężyka o Molskim); wprawdzie Sygiert, jak pisze autor, wahał się „nie w obawie przed zemstą thumacza, choć nie wykluczal takiej możliwości, ale w trosce o rzetelną, całościową ocenę dzieła Dmochowskiego, co wymagało znacznie więcej czasu” (ibidem) - kto wie jednak, na ile drugi powód był uwarunkowany pierwszym?

Przy okazji warto wyraźnie zaznaczyć, że cytowany przez Snopka na s. 89, jako przykład popularyzacji dziedzictwa antyku, wiersz Charaktery ośmnastu wielkich mężów jest w istocie akrostychem imienia NAPOLEON BUONAPARTE - podobny wiersz przytaczam w: Horacy w twórczości Kajetanta Koźmiana, „Meander”, R. 48, 1993, z. 3-4, s. 167. 
Lublin nigdy nie był dostatni w literatów. Z Warszawą mało miałem stosunków. Bywalo wprawdzie u mnie dwóch ludzi uczonych, Seweryn Wedykowski, rektor szkół lubelskich, i ksiądz Radliński zakonnik, eks-prowincjał bernardyński, mówiący kilku językami, długo bawiący w Rzymie i podróżujący, wielce znakomity erudyt, oba i mego brata Józefa, i moi przyjaciele; Wedykowski właśnie zajmował się tłumaczeniem Eneidy Wirgiliusza; oba lubili poezję i sami wiersze pisali, lecz obom nie dostawało smaku, a zatem radom i sądowi ich powierzyć się i zaufać nie mogłem ${ }^{55}$.

Pora zebrać najważniejsze wiadomości biograficzne o Wedykowskim ${ }^{56}$. Urodził się 8 listopada 1755 roku na Podolu w rodzinie szlacheckiej, do szkół uczęszczał w Kamieńcu Podolskim i Lublinie, następnie studiował filozofię i teologię w jezuickim seminarium duchownym w Kamieńcu Podolskim ${ }^{57}$. W roku 1773 otrzymał święcenia kapłańskie. Jego dalsza kariera obejmowała równolegle pracę nauczycielską (w zakresie religii oraz wymowy) w szkołach Lublina, Kamieńca Podolskiego, Krzemieńca i (najkrócej) Krakowa, a także godności kościelne kanonika różnych kapitul, kuratora licznych parafii, jak również sędziego konsystorza lubelskiego. Pod koniec życia sprawowal nadzór nad szkołami lubelskimi jako prałat scholastyk, był także cenzorem ksiąg religijnych. W szkolach Komisji edukacji Narodowej uczył „z dobrej woli” od roku 1780, na emeryturę przeszedł w 1803. Zmarł w Markuszowie 17 kwietnia 1839 roku $^{58}$.

Jego łagodny charakter i dobroć zjednywały mu sympatyków; właśnie jako moderata wybrano go kompromisowo, podczas burzliwego posiedzenia, rektorem szkół lubelskich w 1790 roku $^{59}$. Z czasem - jeśli wierzyć źródłom stronniczym - zapewne jego charakter

${ }^{55}$ K. Koźmian, Pamiętniki, t. 1, s. 301. W tomie 3 (s. 477) Koźmian, mówiąc o swoim wiernym służącym Marcinie Radlińskim, wspomina, że „urodzony w Potoku wzięty był za chłopca do posług domowych przez ówczasowego proboszcza, księdza Seweryna Wedykowskiego"; tam brat poety, biskup Józef Koźmian, „spostrzegłszy w mlodym Radlińskim bogobojność, pokorę i chętną gorliwość do służby, wyjednał u księdza Seweryna Wedykowskiego, że mu go odstapil”. O Salwatorze Ignacym Radlińskim (1751-1825) zob. Stownik polskich pisarzy franciszkaniskich..., red. H. E. Wyczawski, Warszawa 1981, s. 403-404.

${ }^{56}$ Za: E. Idziakowski, Sadownictwo kościelne na terenie diecezji lıbelskiej (1790-1985), mps w Bibliotece Archiwum Diecezjalnego Lubelskiego, s. 358; tamże szczegółowe dane o kościelnych godnościach Wedykowskiego. Podanej tu wiadomości o przynależności Wedykowskiego do Towarzystwa Jezusowego od roku 1770 do sekularyzacji w 1773 nie potwierdza Encyklopedia wiedzy o jezuitach na ziemiach Polski i Litw'y 1564-1995, opr. L. Grzebień i zesp., Kraków 1996 (nazwiska Wedykowskiego brak).

${ }^{57} \mathrm{~W}$ świetle powyższej informacji, potwierdzonej w Archiwum Uniwersytetu Jagiellońskiego, nieprawdą jest, że Wedykowski był wychowankiem Akademii Krakowskiej — zob. I. Szybiak, Nauczyciele szkót średnich Komisji Edukacji Narodowej, Wroctaw 1980, s. 103-104.

${ }^{58}$ Wiadomości o Wedykowskim znajdują się glównie w: K. Mrozowska, Walka o nalıczycieli ślvieckich $w$ dobie Komisji Edukacji Narodowej na terenie Korony, Wrocław 1956; J. Dobrzański, Ze studiów nad szkolnictwem elementarnym Lubelszczyzny w pienvszej potowie XIX wieku, Wrocław 1968; Protokoly posiedzeń Komisji Edukacji Narodowej 1786-1794, opr. T. Mizia, Wroclaw 1969; J. Poplatek, Komisja Edukacji Narodowej. Udzial bylych jezuitów w pracach KEN, Kraków 1973.

${ }_{59}$ Zob. Z. Kukulski, Obrady zgromadzeń akademickich Wydzialu Małopolskiego w Lublinie w roku 1790, w: Epoka wielkiej reformy, Studia i materialy do dziejów oświaty w Polsce XVIII w., red. S. Łempicki, Lwów-Warszawa 1923, s. $107-122$. 
musiał dobrze okrzepnąć, skoro w roku 1800 korespondent Jacka Idziego Przybylskiego lubelski nauczyciel Kazimierz Chromiński, donosi o różnych intrygach przeciw swoje osobie przy „natężonym makiawelizmie” rektora, którego oskarża wręcz o despotyzm, i pros o wpłynięcie na Wedykowskiego poprzez zaprzyjánionego z nim szwagra Przybylskiego Antoniego Himonowskiego, prorektora Gimnazjum św. Anny w Krakowie ${ }^{60}$.

Szczupła bibliografia Wedykowskiego obejmuje zaledwie dwa druki. Napisana klarown: polszczyzną, chociaż retoryczna i wielosłowna Mowa $w$ dzień imienin Najjaśniejszego Stanistawc Augusta... do mtodzi szkót wydziatowych krzemienieckich z maja 1785 roku przepełniona jes oficjalnymi, państwowotwórczymi refleksjami o powinnościach obywateli i dobroci monar chy, którego zasługi w dziedzinie edukacji mówca podkreśla ${ }^{61}$. Jej stylistycznym przeciwień stwem jest krótka Przemowa przy zto żeniu do grobu ciała... Franciszka Zabtockiego..., wygłoszon: 12 września 1821 roku w Końskowoli pod Puławami, gdzie komediopisarz, w jesieni życic ksiądz, byl dwadzieścia lat proboszczem ${ }^{62}$.

Więcej materiałów przechowało się w rękopisie Biblioteki Jagiellońskiej, sygn. 6757 II zawierającym prace czytane na posiedzeniach Towarzystwa Przyjaciól Nauk w Lublinie którego Wedykowski był współzałożycielem (w roku 1818) i czynnym członkiem. W'śróc prac innych autorów rękopis BJ zawiera przekłady Wedykowskiego z Georgesa Buffona (Wielkość i wspaniatość natury, k. 2-14), Gabriela Marii Legouvé (Groby, k. 33-42), Charlesa dє Chênedollé (Michat Andzelo, czyli odrodzenie się sztuk, k. 43-47), a także własne Pienie o Boğ (k. 28 v.-31) i Rozprawę o uszanowaniu, które prawdziwa filozofia winna jest dla religii (k. 15-28). czytane w latach 1819-1820 na posiedzeniach lubelskiego TPN ${ }^{63}$. W kręgu prac lubelskiegc towarzystwa uczonych pozostaje te $\dot{z}$ wymieniona w tytule niniejszego artykułu rozprawa.

Recenzję Eneidy w przekładzie Dmochowskiego znamy z odpisu w formie osobnegc zeszytu (43 strony tekstu z poprawkami autora), z kartą tytułową i dedykacją dla Stanisława Kostki Potockiego, pisanymi ręką Wedykowskiego ${ }^{64}$. W dwustronicowej przedmowie recen-

${ }^{60}$ Zob. korespondencja J. I. Przybylskiego, rps BJ 148 t. 4, k. 401-406 (listy K. Chromińskiego z16 III, 11 X] i 30 XI 1800).

${ }^{61}$ Unikat w Bibliotece Ossolineum we Wrocławiu, sygn. XVIII-10844-II (b. m. dr., $4^{\circ}, 14$ s. nlb).

${ }^{62}$ Egzemplarze w Bibliotece Narodowej w Warszawie (sygn. II 342 879) oraz Bibliotece Zgromadzenia Księży Misjonarzy w Krakowie (bez sygn.); druk: Lublin, J. K. Pruski, k. nlb. 4, $4^{\circ}$ (zob. Aneks do niniejszegc artykułu). Mowa potwierdza Końskowolę jako miejscu pochówku Zabłockiego (wątpliwości zgłaszal J. Starnawski, Przyczynki do biografii Kniaźnina, Zablockiego i Piramowicza zebrane z Kurowa i Końskowoli, „Archiwa: Biblioteki i Muzea Kościelne”, t. 7, 1963, s. 276-277).

${ }^{63}$ Zob. Z. Kukulski, Towvarzystwo Przyjaciól Nauk w Lublinie na tle epoki (1818-1830), „Pamiętnik Lubelski”, t. 3, 1935-1937, wyd. 1938, s. XIII-XCII; S. Górski, Towarzystwo Przyjaciót Nauk w Lublinie (1818-1830), „Biblioteka Warszawska” 1905, t. 3, s. 92-124.

„Dla Boga, dajcie pokój tym tłumaczeniom poetów drugiego rzędu! Gdzież teraz, oprócz Warszawy, thumaczą Legouvé i Delila, a co gorsza, Milvoie etc.? Rosjanie kiwają głowami z litości i z podziwienia" pisał do Antoniego Edwarda Odyńca w listopadzie 1827 roku z Moskwy Adam Mickiewicz (Dzieła, t. 14, s. 355). Były to stowa o tyle nietrafne i niesprawiedliwe, ze wlaśnie u Charlesa-Huberta Millevoye (1782-1816) znaleźć można zarówno Ballady, jak i Romanse... (zob. Oetwres complètes de Millevoye ..., t. 1, Paris 1827, s. 311-333: Ballades; s. 335-348: Romances).

${ }^{64}$ Dawniej AGAD ApP 211, od 1955 roku w Bibliotece Narodowej w Warszawie, sygn. BN II 6854 (mikrofilm BN 32593). 
zent ze względu na mlodzież szkolną postuluje następne, już poprawione wydanie utworu, bowiem usterki pierwszego „odstręczyć mogą od czytania całego dzieła (...), z której [Eneidy — JW] oryginalem lepiej się obeznali Polacy jak z Iliada (...)” (s. 4-5). Wedykowski bardzo mocno akcentuje etyczny i patriotyczny walor nauki łaciny:

Poznała młodzież polska, ile na obojętnym przykładaniu się do tego języka straciła; w nim albowiem przodkowie jej czerpali gruntowność myśli, zdań, moc wyrażeń, i tego ducha wolności, którym tchnęli Rzymianie (s. 5).

Zasługę rozszerzania zakresu nauki łaciny w szkołach autor pisma przysądza ministrowi Potockiemu, jego też decyzji zostawiając ponowną edycję „dla użytku szkół krajowych i wdzięcznej pamięci zmarłego" Dmochowskiego (s. 4). Ministra oświecenia ująć ma także przytoczenie dwuwiersza z Listu do Pizonów Horacego (w. 347-348) w przekładzie nieżyjącego brata Potockiego, Ignacego, słynnego działacza patriotycznego z okresu Sejmu Wielkiego $^{65}$. Ars poetica ma być argumentem usprawiedliwiającym niedoskonałość propozycji zmian:

Nie podchlebiam sobie, żebym w tym względzie skutecznie usłużyl, ale może kto trafniej, z gorliwości o wybór dzieł polskich, moim zachęci się przykładem (s. 5).

Uwagi Wedykowskiego, ale wyłącznie do księgi pierwszej, znajdują się też w zbiorze litterariów Archiwum Publicznego Potockich ${ }^{66}$. Podobna w treści przedmowa uboższa jest o trzy ustępy, w tym apel do Potockiego o powtórną edycję Eneidy Dmochowskiego. Zarówno krótsze rozmiary calego tekstu recenzji, jak i zwrot w przedmowie do „bezstronnej publiczności” (w rękopisie BN: „światłych czytelników”) każą przypuszczać, że właśnie ten fragment, a nie rękopis BN, Wedykowski czytał na pierwszym publicznym posiedzeniu Towarzystwa Przyjaciół Nauk w Lublinie 18 października 1818 roku 67 .

Wedykowski nie chce być krytykiem gołosłownym - oto najobszerniejszy w rękopisie BN przykład argumentacji, stylu i własnych propozycji (w rękopisie ApP to miejsce omówiono krócej):

"Ja, com na wiejskim flecie nucił rym pieskliwy,

Potem, wyszedłszy z gajów, zniewoliłem niwy,

By chciwości rolnika wyrównaty plonem,

Wdzięczne dzieło wieśniakom, dziś wznioślejszym tonem

Broń i męża opiewam, co losy wiecznemi

Uszedłszy z Troi, przybył do italskiej ziemi” [I wst., 1-2]

${ }^{65}$ Pierwodruk przekładu Ignacego Potockiego De arte poetica Horacego: „Nowy Pamiętnik Warszawski” 1801, IV, nr 10, s. 94-107.

${ }^{66}$ Sygn. AGAD ApP 242, s. 257-266.

${ }^{67}$ Relacja: Dodatek do „Gazety Warszawskiej”, nr 92, 17 XI 1818, s. 2323; omówiona i cytowana przez

Z. Kukulskiego, Towarzystwo Przyjaciót Nauk..., s. LVII. 
(...) Nucić na flecie rym, a jeszcze pieskliwy, nie zdało mi się, carmen albowiem nie tylko oznacza rym, ale też pieśń, która bardziej służy fletowi oddającemu pewną głosu harmonię; może i w tym znaczeniu wziął Wirgiliusz. W naszym języku niekoniecznie ten sposób mówienia brzmi właściwie, jak zniewolenie niw do wydania plonu, nie wspomniawszy, ile w polskim języku, o uprawie ziemi. Zniewalamy ludzi przekonaniem, prośbą, datkiem, ziemi zaś bardziej służy przymus, jak użył Wirgiliusz: coegi. Chciwość rolnika nie w każdym się kraju okazuje; nasi rolnicy dosyć są szczęśliwi, kiedy prace swoje mają wynadgrodzone. Wznioślejszy ton, do którego się sam Wirgiliusz nie przyznaje, pisząc wiersz bohatyrski, mniej potrzebny się być zdaje, bo go same dzieło obwieszcza. Włochy u nas właściwiej się mówią niżeli z lacińskiego przekształcony wyraz: italska ziemia (...)

Ja, nie przywięzując się co do słów, bardziej językowi naszemu chcąc usłużyć, tak bym się tłumaczył:

Jam, co śpiewal pasterski bieg życia szczęśliwy,

Potem sztuką uprawy przymusiłem niwy,

By wskutek prac rolnika plon wydały hojny,

Teraz opiewam męża i krwawe $z$ nim wojny,

Co po zburzeniu Troi nie mając widoków,

Przybył do Włoch, wygnaniec z niebieskich wyroków.

Albo:

Ja, com opiewał życia wiejskiego ponęty

I uczył, jak uprawiać grunt pługiem nietknięty,

Plenny zaród rolnika by nadgrodził znoje,

Srogiego teraz Marsa krwawe śpiewam boje

I męża, który z Troi pożarów wyrwany

Przybył do Włoch losami wiecznymi przygnany.

Znaczną większość uwag i proponowanych zmian Wedykowski uzasadnia, w zaledwiє dwudziestu przypadkach (czyli jednej szóstej całości) poprzestając na ogólnym: „Wolałbym...” czy „Mnie by się zdało..." ${ }^{68}$. Poprawki dotyczą zazwyczaj zwrotów, fraz czy pojedynczych wyrazów, uzytych — zdaniem recenzenta - wbrew regułom. Nie chodzi przy tym o zasady ściśle sformułowane. Rzadko też są to kryteria bezwzględne, jak na przykład logika wypowiedzi:

${ }^{68}$ Uwagi Wedykowskiego lokalizuję wobec edycji Eneidy Dmochowskiego z 1809 roku (ozn. „Dm.”; numeracja wersów uściślona przeze mnie, zwłaszcza w ks. III) i za tym wydaniem koryguję brzmienie cytatów; przy rozbieżnościach dodaję lokalizację oryginału (ozn. Aen.) Wersje dwudziestowieczne czerpię z wydań: Wergiliusz, Eneida. Epopeja w divtnastu ksiegach, tt. I. Wieniewski, Kraków 1978; P. Vergilius Maro, Eneida, t1. i opr. Z. Kubiak, Warszawa 1987. 
„Z tak miłego wzmożeni na sercu widoku” [Dm. I 595] - Nie sam tylko miły widok chęć ich wydobycia się z obłoku powiększał, ale mowa Dydony, przy końcu wiele Eneasza obowiązująca;

"Już ogromnego szyi ciężaru nie dźwigal” [Dm. III 649] — ...raczej głowy, pod której ciężarem szyja się nachyla;

„Cień mój wszędzie cię goni...” [Dm. IV 403] — Jeszcze Dydo żyła, to mówiąc, a więc cień dopiero na potem Eneasza miał gonić.

Czasem krytyk tropi subtelniejsze odcienie znaczeniowe wyrazów:

„Utkwił drgający pocisk...” [Dm. II 55] - Mówi się: członki d r g a ją, mające ruch silniejszy od duchów żywotnich, spiritus vitales, ale pocisk pospolicie tylko dr ży;

„Wpadli na miasto we śnie zagrzęzłe i w winie" [Dm. II 274] - Sepultam nie to jest co z a g r z ę z łe, skąd się jeszcze ratować można, ale p o g r ą ż o n e...;

„...Pikus, kiełznacz koni” [Dm. VII 190] - ...g r o m c a koni — jako umiejący je zażyć w szalonych zapędach.

Częściej Wedykowski powoluje się na uzus językowy („Kiedyż się taki sposób mówienia w polszczyźnie używa?" - z komentarza do Dm. I 333-334), wytykając thumaczowi zarówno grubiaństwa, jak i zbyteczne finezje. Skrupuły recenzenta bywają dla dzisiejszego użytkownika polszczyzny zaskakujące, jak na przykład dwukrotnie wypomniana forma zaimka „tutaj” (Dm. I 472 i II 806; „wyraz pospolity, zdaje się być dosyć w wierszu nieprzyjemny”), odrzucenie jędrnego regionalizmu:

„Ci na zielonej trawie w dużaniach się ćwiczą” [Dm. VI 663] — „Prosty i na Rusi tylko używany wyraz $\mathrm{d}$ u ż a ć s i ę dla doświadczenia sil zręczności;

lub krytyka miejsca:

„...tak Eneasz prawi” [Dm. II 2] - Bo prawić w języku naszym znaczy coś nie do rzeczy gadać, wyraz nadto pospolity.

Wprawdzie można zgodzić się z uwagą:

„Fauny, nimfy tu zlęgłe trzymały te gaje” [Dm. VIII 324] — Obok nimfy wyraz (...) jest niegrzeczny dla panien, zamiast: wychowane.

Podobnie niezręcznie, również zdaniem recenzenta, określono młodzieńców, którzy podziwiali Kamillę, „Zdumione na idącej utykając oczy” (Dm. VII 832). Jednak Wedykowski niezbyt korzystnie zastępuje podobny zwrot: 
„Gdy w ostatniej żegludze w gwiazdach utkwił oczy” [Dm. VI 347] — Pospoliciej się mówi: wlepił w gwiazdy oczy;

a zdanie „Z całych Włoch liczne do niej brały się młodzieńce” (Dm. VII 54) krytykuj wyłącznie z pobudek semantycznych (,Petebant nie znaczy brać się, ale starać się, ubiegać si o czyjąś przyjaźń”), nie zaś - jak spodziewalibyśmy się - stylistycznych ${ }^{69}$.

Postulowane uproszczenia z kolei dotyczą zbytniej dosłowności tłumacza:

„Niosą Cererę mokrą i Cerery sprzęty” [Dm. I 184] - ...mógł Rzymianin użyć tego wyrazu, z którym się oswoil, język nasz bez tego bóstwa obejść się może... [podobna krytyka Dm. VII 114: „Zgryźć i Cererę drobną...”];

„Na oczach miasta Tened, sławna wyspa, stoi” [Dm. II 23] - Mnie by się zdawało: „Blisko dość miasta...”;

"Już stary, lecz się starość jędrnością zieleni" [Dm. VI 314] - Mowa tu o Charonie. Zielenić się jędrnością człowiekowi nie wypada, za śmiała przenośnia;

„Tam Latynus poświęcił sto bydląt dwuzębnych” [Dm. VII 94] — „Sto owiec zabić kazał Latyn na ofiarę";

a także własnych, wątpliwych pomysłów Dmochowskiego:

„Wszyscy morze licznymi zamiatamy wiosły” [Dm. III 685] — W pospolitym znaczeniu zamiatać jest jedno, co oczyszczać, a morzu to ochędóstwo nie przystoi;

„I drogę do lask męża dawnego uściele” [Dm. VI 543] — ...nadzwyczajny jest sposób mówienia, lepiej: „ująć serce męża” (...).

W kilkunastu wypadkach Wedykowski, chcąc rzecz ująć „zwyczajniej”, „pospoliciej”, „wlaściwiej” czy „znośniej”, atakuje zarówno wybujałe obrazy:

${ }^{69}$ Dbalość Wedykowskiego o decorum obrazuje zmiana, jakiej dokonal milcząco w cytacie $z$ „ody rzymskiej' Horacego (c. III 6,1-4), użytym jako przypis do Rozprawy o uszanowaniu, które prawdziwa filozofia tvinna jest dla religii z 1820 roku (rps BJ 6757 II, k. 17a):

Grzech przodków, choć bez waszych win, zacni Rzymianie,

Karą wam będzie, póki świątnic nie dźwigniecie,

Póki z gruzów na nowo oltarz nie powstanie

I skopcone posagi z prochów nie otrzecie.

U Piotra Krukowieckiego (Pieśni wszystkie Horacjusza przektadania różnych, t. 2, Warszawa 1775, s. 71):

Póki boży $z$ obalin ołtarz nie powstanie

I nie zejdzie z posągów zakurzonych śmiecie. 
Na pozór szumny opis, ale zastanowiwszy się z uwagą, nie będzie się podobał ani kocioł buchający, ani gorące potoki, użyte z wielką przysadą... [uwaga do Dm. VII 474-476 = Aen. VII 462-465];

Taki opis tylko bez doświadczenia młodzieży podoba się, żeby warczący oszczep, którego nie tak przeraźliwy lot bywa, zatonął w mózgu tak szczupłym, jak jest człowieka [uwaga do Dm. IX 425-426 = Aen. IX 418-419];

jak i krótsze odcinki tekstu:

"Więc gdy trąba huknęła..." [Dm. V 140] - Wolałbym: zabrzmiała, jak się pospoliciej używa;

„Widzowie zachęcają, wrzask bije niebiosy" [Dm.V230] — ...nadto przesadne, dość by było powiedzieć: idzie;

D rogę ciąg nąć nie zdaje mi się [uwaga do Dm. V2]; Można by zwyczajniej powiedzieć: dążą [uwaga do Dm. VI 395].

Oprócz ewidentnych niezręczności stylistycznych jego krytyce podlegają również zwroty utarte w języku polskim lub nie naruszające żadnych norm poprawnościowych. O ile słusznie recenzent pyta:

Glos ciągnąć z piersi - czyliz jest prawdziwym żalu wyobrażeniem? [uwaga do Dm. I 381];

o tyle trudno pojąć zastrzeżenia:

„I do pól ciała wdzięki roztacza dziewicze” [Dm. III 438] — Roztaczać wdzięki nieco jest przysady;

„Ale że Wlochy w możność, w zwycięstwa brzemienne” [Dm. IV 241] Brzemienność zwycięstwom nie służy, tak przynajmniej zdaje mi się;

„Wyroki tak okrutne serce w nim krajały” [Dm. VI 341] — ...właściwiej mówi się: rozdzierać;

„...Lecz Noc smutnym oblała go mrokiem” [Dm. VI 899] — Właściwiej by było: zajęła.

Niezbyt przekonują też wyjaśnienia:

„Czuje pierś skołataną niezmiernym kłopotem” [Dm. VIII 20] - Kłopoty właściwiej serce dotykają jak piersi;

"Wenus rozlewa słodki sen w czlonki dziecięce" [Dm. I 711] - Rozlewać w członki sen nie zdaje mi się, który więcej duszę zajmuje. 
Wedykowski tępi określenia zmysłowe, zarówno konkretne:

„Odwróciła się, szyją błysnęła różową” [Dm. I 412] — ...szyją prześliczną błysnęła;

„Złote łańcuchy mleczne otaczają szyje” [Dm. VIII 677] — ...ksztaltne, piękne;

„Do niego różanymi usty Iris mówi” [Dm. IX 4] — ...powabnymi usty (...);

jak i przenośne:

„Ani dasz ucieszyć się uścisku słodyczą” [Dm. I 418] - Słodycz uścisku nie wiem jak się udziela, raczej: tkliwe uczucie.

Odrzucając niektóre dynamiczne zdania i określenia, autor recenzji sięga czasem pc argumenty logiczne:

"Skrwawilibyśmy bronią ten potwór ogromny" [Dm. II 58] - Skrwawić bronią potwór, a jeszcze drewniany, nie służy;

czy nawet psychologiczne:

„Znowu mię przeciw Grekom wściekła myśl porywa” [Dm. II 688] — Wściekła myśl nadto człowieka upokarza.

Czasem oznajmia tylko (przy szczególnie udanym wersie Dmochowskiego o Circe):

„W zwierzęce kształty ludzkie przewierzgła oblicze” [Dm. VII 20] — Znośniej by było: zmieniła.

Dążenie do osłabienia emocji i wyrównania języka wypowiedzi poetyckiej dominuje w uwagach Wedykowskiego, który zacytowane powyżej przykładowo wersy chciałby widzieć w zneutralizowanej postaci:

Żeby bronią dziwotwór ten zburzyć ogromny [do Dm. II 58];

Znowu mię przeciw Grekom chęć pomsty porywa [do Dm. II 688];

czy zamiast obrazowego wersu Dmochowskiego:

"Siedli rzędem, u wioseł natężeni wiszą" [Dm. V 137] - Siedli rzędem, a wiosła wziąwszy w ręce obie, / Czekają...

Gwoli prawdzie trzeba zauważyć, że w kilku miejscach wersja Dmochowskiego wydała się recenzentowi — na odwrót — zbyt anemiczna: 
„...zarazem je orze / Eurus, Not, słotny Afryk...” [Dm. I 89-90] — Wyraz przenośny or a ć nie służy tu wodzie, ale ziemi, którą rolnik powoli przewraca, wiatry zaś gwałtowniej działają;

„Dotknąwszy córki lica, smutne troski koi” [Dm. I 263] — ...o, jak ozięble wyrazy te oddane, żeby dotknięcie obojętne miało zastapić pocałowanie!;

„Niekiedy zapał dawny zwyciężonych grzeje” [Dm. II 380] — ...słaby jest wyraz porywczości bój staczających [podobnie do Dm. IV 284: „Jeśli cię wielkość twoich przeznaczeń nie grzeje"];

„Poczuł, i na dźwięk głosu szedł olbrzym wyniosty” [Dm. III 686] — ...można by użyć za dźwięk - huk, chrzęst [podobnie Dm. VIII 434: „I w piecach ogień ciaggtym szumieje loskotem" - Wolałbym: szturmuje, lub: gwar, huk czyni toskotem];

„Skazaly piekieł kraje, te miejsca wybladte” [Dm. VIII 248] — ...miejsca wybladłe słabo wyrażają miejsc tych okropność, którą im przydać należało [niewiele jednak „przydają okropności” poprawki Wedykowskiego do tego miejsca: „Wskazały piekła kraje z ludzkości wyzute” lub „Wskazuje piekła kraje i straszne widziadła”...].

Są to jednak wyjątki od generalnie przyjętej przez Wedykowskiego - acz nie ujętej w paragrafy — zasady poprawności stylu. W przytaczanych powyżej uwagach można jeszcze dostrzec różnice między wersją Dmochowskiego a propozycjami zmian, lecz sporą część modyfikacji uznać należy za wersje fakultatywne w świetle normy języka ogólnego. Innymi słowy: „poprawki” Wedykowskiego stają na równi z „błędami” Dmochowskiego. Nie wiadomo, czemu koń trojański ma „wyrzucać” lub „wywnętrzać” z siebie rycerzy zamiast „wylewać” (Dm. II 339); czym „wyziew” różni się od „powiewu piorunu” (Dm. II 668); czemu "wierzchołki”, a nie "górne żaglów rogi” (Dm. III 564). Dlaczego „zakryte, zaćmione, oblane”, a nie „pianą... zroszone niebiosy” (Dm. III 582)? Skąd „podług możności” zamiast „wedle przemogi” (Dm. V 103)? Z jakiej przyczyny „razi”, gdy u Dmochowskiego „dech suche usta bije" (Dm. V 202); co spowodowało ,jak najczystsze”, a nie "otworzystsze powietrze” w Elizjum (Dm. VI 660)? Czym wreszcie różnić się ma „obecnie” od „oblicznie” (coram, Dm. VIII 125 = Aen. VIII 122-123), ,jak daleko sięga" od ,jakich końców sięga" (Dm. VIII 15, stpol. „koniec” w sensie „cel”) albo „wyroki... zmienil boże” od „zgiął wyroki boże” (Dm. VI 387)?

Trzy ostatnie przykłady unaoczniają, że recenzent, starszy wprawdzie od Dmochowskiego, mniej pobłażliwy był dla reliktów staropolszczyzny i odbierał je jako wyraźny dysonans, w czym jednak nie był całkiem konsekwentny. Nie podobał mu się na przykład fachowy, a przy tym jakże energiczny brzmieniowo „cymbulc” (Dm. IX $722=$ Aen. IX 705; z niem. Zündbolz) na oznaczenie „falaryki”, oszczepu z płonącymi pakułami. Lecz bywa, że poprawki 
wprowadzają wyraźniejsze archaizmy lub dotyczą nie tego, czego spodziewalibyśmy się znając język początku XIX wieku. W istocie, zwrot „żywot stoi za: pokąd żyjesz — niemil w uszy wpada", ale przy okazji poprawy pierwszej polowy dystychu:

„Wielki wodzu, którego kiedy żywot stoi,

Ja jeszcze nie uznaję za zniszczoną Troi” [Dm. VIII 481-482]

Wedykowski psuje drugą połowę:

Wielki mężu, gdy żyjesz, ja pod twą zachroną

Nie uznaję na zawsze Troję być zniszczoną.

Niezbyt zgrabny dwuwers:

„Rzecz wielką obiecują, naradę przysporzyć.

Wpuścił Julus i kazał, z czym przyszli, otworzyć” [Dm. IX 237-238]

Wedykowski zastępuje nie lepszym:

Rzecz wielką obiecują, naradę zabawić,

Wpuścil Julus i kazał, z czym przyszli, objawić.

Nie odpowiadająca ściśle oryginałowi (Aen. II 391-392) „Androgeja przyłbica z pływająca kitą” (Dm. II 405) ma chociaż więcej rycerskiej powagi niż zaproponowana „chwiejąca się kita”. Tymczasem „byt w niebie wytknięty” (Dm. I 257), krytykowany przez Ludwika Osińskiego, nie zwrócił uwagi lubelskiego recenzenta.

Stosunkowo niewiele miejsc w Eneidze Dmochowskiego wymienionych przez Wedykowskiego uznać można za skrytykowane słusznie, oczywiście na tle systemu językowego przełomu XVIII i XIX stulecia. Niewątpliwie należy do nich „szkarłatnica” jako rym do „prawica” (Dm. VII 255-256), „Boga miejsca... postać spoważniona” (rym: „ramiona”, Dm. VIII 33-34) czy zdanie:

...widzimy $z$ daleka

I Gelę straszną, którą tak nazwała rzeka [Dm. III 717-718].

Przesadził niewątpliwie Dmochowski, pisząc - zapatrzywszy się na sztychy Piranesiego?... - o „wnętrza ogromnych pieczarach” drewnianego konia (Dm. II 40), w którego „Ślepym boku” (Dm. II 268) kryć się mieli Achaje. Przekonująco brzmi też uwaga do wersów:

„Albo wrzucić do morza podstęp grecki każą,

Albo ogniem otoczyć podejrzane dary" [Dm. II 38-39] -

Podstęp, wyraz umysłowy [abstrakcyjny - JW], nie wypadało wrzucać do morza (...). Nie dosyć bylo w wierszu o t o c z y ć ogniem, ale zniszczyć. 
Podobnie puklerz „z dwóch grzbietów ubity” (Dm. IX 723) „nie dodawszy: wolich (...) nie zdaje mi się", i nam też. Wypada również zgodzić się, że dosłowny przekład prowadzić może do niezrozumiałości (realia mitologiczne w rodzaju wspomnianej „Cerery”, „zieleniejąca starość” Charona czy omijane i przez współczesnych tłumaczy „bydlęta dwuzębne”) lub niezręczności:

„...Troja z górnych szczytów pada” [Dm. II $300=$ Aen. II 290] - Szczyt uważam wierzchołek czego, co Troi nie służy;

czy „zasklepiałe serca w Penów łonie” (Dm. I 583), na które zwracał uwagę również Osiński.

Znacznie więcej jednak jest uwag dyskusyjnych, wątpliwych, a są i calkiem błędne z banalnej przyczyny mylnego odczytania tekstu Dmochowskiego. W wersie „Znieśliście większe razy...” (Dm. I 204) Wedykowski proponuje „zmianę” na... „razy”, bo odczytał lub zapisał sobie „większe r z e c z y” i wolał „coś tkliwszego umieścić”. Konstatuje:

„I Juno broni dalej iść Helena radom” [Dm. III 391] — Iść czyim śl a d o m nie zdaje mi się;

„W takich się modłach bogom głębi [głębin morskich - JW] upokorza” [Dm. V 236] — Głębić się i upokarzać zdaje mi się być jednoznaczne wyrazy (...).

„Brzmiący czolnek” (Dm. VII 14), więc czólenko tkackie, odczytane jako „czlonek”, Wedykowski zamienia na „sztuczną igłę”, zaś błędna interpunkcja cytatu „Kują, ogromny obwód ukształcają tarczy” (Dm. VIII 459; u recenzenta: „Kują ogromny obwód, ukształcają tarczy”) spowodowała uznanie przezeń przydawki za dopełnienie w 2. zamiast 4. przypadka.

Do miejsc dyskusyjnych należy zwłaszcza passus o samobójcach (Aen. VI 434-436, Dm. VI 447-448). Czy są oni „szaleni”, czy tylko „niewinni”? Dmochowski, podobnie jak dziś Zygmunt Kubiak ${ }^{70}$, tłumaczy lagodniej:

Obok smętne tych cienie, którym będąc męką

Życie, bezwinnie własną rzucili je ręką.

Wedykowski argumentuje:

Insons w lacinie nie tylko znaczy niewinny, ale też nieczuły, bez przytomności i uwagi, co pospolicie się zdarza odbierającym sobie życie.

W tym duchu wcześniej tlumaczył też Molski ${ }^{71}$.

70 „Którzy, niewinni, zabili się sami” — w. 599, s. 195.

71 „Dalej poczet frasownych następuje cieni, / Szaleńców...” (Ogloszenie dziela pod tytutem „Eneida”..., s. 14:

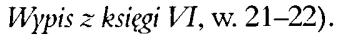


W mniejszym stopniu dyskusyjny jest obraz Askaniusza, który szyje z łuku, „strzałę ná końskiej natężywszy żyle” (Dm. IX 636). Chodzi tu raczej o zwierzęce jelito, nie zaś, jak chcє Wedykowski, o „cięciwę u łuka z końskich włosów”72.

W kilku miejscach ani tłumacz, ani recenzent nie mają racji. W scenie obalania górskiegc jesionu (Aen. II 631) Dmochowski zrozumial iugum (tu: grzbiet góry, z którego wieśniac) wyrywają drzewo z korzeniami) mylnie jako iugerum, 'mórg ziemi', tłumacząc: "Jęknął zwaliskiem cale okrywając łany". Recenzent uznał to za prawidłowe, choć przesadzone i zaproponował wersję: "Jęknął, zwaliskiem znaczną część okrywszy ziemi”. Orestes (Aen III 331) - u Kubiaka „pędzony Furiami zbrodni”, u Wieniewskiego „ścigany za zbrodnic przez Furie"73 - jest w wersji Dmochowskiego (III 340) „od Jędzy dręczących do zbrodn popchnięty”, co Wedykowski zmienić chce na: „Zbrodniami jakby od jędz piekielnyck dręczony”. Z rzeczy weselszych wskazać można zabawny dość spór tłumaczy, którym bliższe były salony niż prosty byt pasterski, a ubóstwo Wergiliuszowego Ewandra nie pasowało dc jego królewskiego majestatu. Goszcząc Eneasza, Ewander przybyszowi „usłany z liścia / Da] stołek, niedźwiedzicy skórą powleczony” (Dm. VIII 378-379), na co Wedykowski nastaje: sensownie zresztą: „Coś musiało być obszerniejszego jak stołek”, ale trafia kulą w płot, chcąc by gospodarz „Dał sofę, niedźwiedzicy skórą powleczoną”.

Kilkakrotnie Wedykowskiemu nie przypadły do gustu zdania, będące wprawdzie własnymi dodatkami czy modyfikacjami tłumacza, lecz dobrze pasujące stylem do kontekstu i zachowujące sens oryginału. W linijce „On rodaków obdarzy i prawem, i domem” (Dm. I 272) recenzent domaga się dosłownego przekładu „moenia” ('mury'); podobnie krytykuje „Erramus” ('Błądzimy', Aen. I 333) oddane jako „krok zwracamy ślepy” (Dm. I 340). O „skrwawieniu” drewnianego konia (Dm. II 58) była juz mowa. Cyklopi (Aen. III 678), „wznoszący aż do nieba nadpowietrzne głowy” (Dm. III 696), tracą u Wedykowskiegc wizualną wielkość, za to nabierają — nieobecnej w tej scenie oryginału - pewności siebie:

Wznoszący aż do nieba harde swoje głowy.

Ale oprócz inwencji także wierność tlumacza bywa naganiona, nie tylko tam, gdzie — jak widzieliśmy - utrudnia odbiór tekstu, lecz i w miejscach najzupełniej poprawnych. Rada dla Menetesa: „I staraj się wiosłami głazy otrzeć w biegu” (Dm. V 164) nie oznacza, jak chce Wedykowski, wezwania, by „głazy trafiać w biegu”. Wici wodzów etruskich rzeczywiście „obnażają szerokie z rolnika zagony” (Dm. VIII 8) i przyimek „z” nie jest błędem drukarskim. Obrazowe i zgodne z oryginałem „uśpione popioły” (Dm. VIII 553 = Aen. VIII 542) slabna poetycko jako „przegasłe popioły”. Luperkal to w istocie „z i e l o n a Marsa jama” (Dm. VIII 646), a nie jaskinia, „której czasem na ozdobie nie zbywa”, więc „piękna”. Podobnie „żywe głazy” (Dm. I $174=$ Aen. I 167) to nie „siedzenia marmurowe”, choć rzeczywiście niełatwo

\footnotetext{
72 Chociaż tak thumaczy Ignacy Wieniewski (w. 614, s. 253); Kubiak wybrnąi: „Strzałę do końskiej cięciwy/ Przytknął" (w. 868-869, s. 296).

${ }^{73}$ Kubiak: w. 457-458, s. 107; Wieniewski: w. 328, s. 86.
} 
przełożyć od razu określenie Wergiliusza na obraz ${ }^{74}$. Wedykowski nie rozumie skrótowej nazwy „Pola Płaczące” (Dm. VI 454 = Aen. 441) i ukonkretnia ich opis w sensie „dusz płaczących”, które „wałęsają się, płacząc, po polach”. Również „rogaty Tyber” (Dm. VIII 80) nie przywoluje recenzentowi na myśl personifikacji rzek w plastyce antycznej (leżące męskie postacie, często z rogami), więc nowe tłumaczenie opiera się na spekulacji, że cornus znaczy „wylew, zatokę, zgola przymiot nadający jej nad inne wyższości” i brzmi:

Tybrze włoski, przewagę co masz nad wodami.

Trochę więcej wyrozumiałości trzeba mieć dla interpretacji tajemniczych „dwóch bram snu” i dwu kategorii zjaw (Aen. VI 894-897). Wedykowski zastępuje „prawdziwe widziadła” (Dm. VI 928) zdroworozsądkowymi „obłędnymi cieniami”. Trudno jednak pojąć, dlaczego od „bramy z roga” ('wykonanej z rogu', Dm. VI 927) „co innego jest brama rogowa”, w dodatku „tak nazwana może od zejścia się ulic"! ${ }^{75}$

Dochodzimy do najciekawszej chyba grupy uwag, będących sporem nie tylko $z$ polskim tłumaczem, lecz także - horribile dictu! - z pierwowzorem. Jak zauważa znawca,

...w żadnej recenzji nie dopuszczano myśli o możliwości poprawienia oryginału, a więc odstępowania od niego, jeśli autorem był Homer, Wergiliusz, Horacy, Cycero lub inni pisarze starożytności ${ }^{76}$.

Tymczasem Wedykowski kilkakroć podważa tekst samej Eneidy w miejscach oddanych przez Dmochowskiego wiernie. Ujmując - wyjątkowo - zasadnicze kryterium oceny $w$ formie sentencji, recenzent stosuje (dostrzeżoną już przez wzmiankowanego badacza) ${ }^{77}$ podwójną skalę wartościowania wobec twórców i wobec przekładowców:

Co się oddala od natury, śmiesznym się być zdaje. Tę przysadę Wirgiliuszowi można darować, ale nie tłumaczowi [uwaga do Dm. VII 285-286].

W imię tej zasady Wedykowski uznaje za „przysadę” i „Ksantem nazwan szczuply strumyczek bez wody” (Dm. III 362; „coś jednakże z wody przydać mu należało, np.: ledwie toczy wody”), i Cyklopa, który „gwiazdy glową bije” (Dm. III 636; „dosyć, kiedy siągnie obłoków, np.: Sam wyniosłej postawy, głowę w obłok kryje”), i „konie ogniste, / Wyrzucające

${ }^{74}$ Kubiak pozostawia domyślności czytelnika „żywe głazy” (w. 231, s. 43), Wieniewski opuszcza szczegól, pisząc: „ą głazy niczym siedzenia” (s. 29).

${ }^{75}$ Dopasowanie „prawdziwych” i „złudnych” snów do różnych wrót na ich przejście (róg lub kość słoniowa, “ Kubiaka „eburn”), bierze początek zapewne z gry słów języka greckiego (zob. komentarz Kubiaka, s. 434). Skoro jednak w poemacie Wergiliusza mają one już - utrwaloną przez Homerową tradycję — materialną dosłowność, dochodzenie etymologii (jak próbuje czynić to Wedykowski) byłoby przekroczeniem kompetencji tłumacza.

${ }^{76}$ J. T. Pokrzywniak, Thumaczenia z literatur obcych..., s. 70.

77 Ibidem, s. 65-66. 
nozdrzem dechy płomieniste" (Dm. VII 285-286 = Aen. VII 280-281). Poważa się nawet n homeryckie porównanie (Dm. II 537-538 = Aen. II 516-517):

Żeby gołębice ściskać miały bogi, a nawet skrzydłami, nie zdaje mi się...

Neguje Wedykowski morskie „czarne bałwany” (Dm. V 2; „bałwany pospolicie kolo bialy maja”) oraz "cienie bezkrwiste” (Dm. VI 413 = Aen. VI 401), widząc w nich „cienic wieczyste”. Obszernie też krytykuje scenę Dm. IX 446-448 = Aen. IX 441-443:

Ani piorunowy miecz, ani wtykanie żelaza w usta nie zdaje mi się, a konający nie miałby siły tyle dokuczać.

Dwie uwagi dotyczą „harpii przebrzydlych”:

Pokarm ciągle bezecnym leje się uchodem,

Ostre pazury, usta blade zawsze głodem [Dm. III 223-224] —

...ten opis zdaje się delikatnym uszom nazbyt nieprzyjemnym, lubo go użył Wirgiliusz. (...) nasz język nie przywykł do tej otwartości. Czy-li by znośniej nie było:

Stworzone na przyjemnych przedmiotów zagładę

Ostre pazury mają, usta głodem blade - ?

Wedykowski lagodzi też „niewzględny opis”:

Z kolczystymi szponami zbiega ród plugawy

I bezecnymi usty szkaradzi potrawy [Dm. III 239-240],

zastępując go swoim:

...Z kolczystymi szponami i chrzęst czyniąc skrzydty,

Wkoło lecąc, zniża się ród do nas obrzydły.

Chwyta potrawy, resztę obrzydza widocznie...

W tej zresztą kwestii recenzent jest nieodrodnym wychowankiem epoki, która już wcześniej (piórem Jeana d'Alemberta) wyrokowała:

Nie dla poznania wad pisarzów starożytnych tłumaczymy ich na nasz język, lecz dla zbogacenia literatury naszej tym wszystkim, co doskonałego zrobili; tłumaczyć ich częściami nie jest to ich obcinać, jest to malować ich z boku i pochlebniej dla nich. Jaką rozkosz wzniecić może w tłumaczeniu Eneidy Wirgiliusza to miejsce, gdzie nieczyste Harpie plugawią i porywają Trojan strawę $(\ldots)$ ? $^{78}$

${ }^{78} \mathrm{~J}$. le Rond d'Alembert, Observations surl'art de traduire. Postrzeżenia i uwagi nad sztuką thumaczeń, th. S. Kłokocki, opr. J. Wójcicki, Warszawa [1995], s. 37. 
Z podobnych przyczyn Wedykowski pragnie „w języku naszym wydać skromniej” fragment:

Tu miłość byka, z bykiem złączona ukradkiem

Pazyfae, i brzydkich co byl ogniów świadkiem

Minotaurus, z dwóch kształtów złożony płód srogi... [Dm. VI 25-27],

uzyskując następujący efekt:

Tu milość stawia oczom wszeteczne przymioty,

Tu Pazyfai sprosne wyryte zaloty,

Tu Minotaurus potwór, skutek niebios kary,

Zabytki i bezwstydnej Wenery ofiary...

Ganiąc pomyłki tłumacza, moderując jego zapał, a nawet sprzeciwiając się Wergilemu, Wedykowski nigdzie nie uważa siebie za ostateczny autorytet, lecz zastrzega, zgodnie z duchem przedmowy: „....inna myśl Wirgiliusza, może na nią natrafię”; „tak przynajmniej zdaje mi się”; „może by trafniejsze było...”, czy w zakończeniu:

...zawsze odwoływałem się do światlych czytelników sądu, nie zasadzając się na moim mniemaniu.

Recenzent zajmuje więc pozycję reprezentanta czytającej publiczności, bez aspiracji do wyjątkowości czy artystycznej nieomylności.

Wedykowski skupił się na dziele samego Dmochowskiego, czyli dziewięciu księgach, kwitując trzy ostatnie, tłumaczone przez pijara Wincentego Jakubowskiego, zdaniem:

...szanuję gorliwość tego męża, która była chwalebna w dokończeniu Eneidy

Wirgiliusza, ale podług rady Horacjusza nieobrachowana z swymi siłami.

Dla ilustracji krytyk przytacza trzy wyjątki: X 641-642, XI 825-826 i szczególnie smakowity XI 811-812, gdzie bohaterska Kamilla

Ani na włóczni postrzał nie daje uwagi,

Aż póki ją donośna w cyc nie trafi nagi.

„A zatem i recenzent mógł być od dalszej uwolniony pracy" - podsumowuje, przypominając, ze dzieło przeznaczone jest także dla edukującej się młodzieży, która

...wyższą teraz biorąc oświatę, nie tylko wierność w tłumaczeniu, ale ozdób $\mathrm{i}$ innej harmonii wiersza wyciąga [wymaga - JW].

Spośród ksiąg przełożonych przez Dmochowskiego najwięcej razy cytowana jest księga pierwsza (20, w tym trzy miejsca inkryminowane też przez Ludwika Osińskiego: Dm. I 174, 184 i 583); następnie druga (17 razy), szósta i ósma (po 16 razy), trzecia (15), siódma (13) 
oraz piąta i dziewiąta (po 9 wyjątków). Najmniej roboty wymagała „dosyć poprawna” księg czwarta (4 cytaty), bowiem tlumacz wykorzystał przeklad początku tej księgi (Aen. IV 1-168 Stanisława Trembeckiego ${ }^{79}$

...i porównać się z nim usiłował; jakoż się nie pomylił w swoim zawodzie.

Recenzję zamyka Wedykowski uwagami o profesji tłumacza, od którego wymaga czuci „powabów i piękności w samej naturze”, ponieważ przy nieuchronnej różności języków

...trzeba malować w języku ojczystym przedmioty z tą zręcznością, żeby się ziomkom podobać mogły.

Po ostatnim już komplemencie pod adresem ministra oświecenia publicznego, Potockie. go, znajdujemy testimonia o Wergilim poetów starożytnych, „którym miłość własna nie był: na przeszkodzie", w oryginale i przekładzie własnym autora pisma ${ }^{80}$. Przytoczyl też niezwyk. le intrygujący francuski czterowiersz (choć w marnej ortografii):

Hélas! le jour fatal! le dernier fils du temps

Détruira ce monde fragile,

Et ses plus riches ornements,

Ses cieux, et ses soleils, et les vers de Virgile.

Przełożył go następująco:

Ach, dzień straszny! Syn czasu w okropnej postaci

Kiedyś przyjdzie i zniszczy świat psocie podległy,

I te chlubne ozdoby, których wieki strzegły,

Nieba, gwiazdy i wiersze Marona zatraci ${ }^{81}$.

79 Pierwodruk: „Nowy Pamiętnik Warszawski” 1801 (sierpień), s. 229 i nast.

${ }^{80}$ Ovid. Am. I 15, 25-26; Ars am. III 337-338; Propert. El. II 34, 63-66; Horat. Epist. II 1, 247-250; idem Serm. I 5, 39-42. Wedykowski przytoczył także epigram pseudo-Korneliusza Gallusa z rękopisu Vatic. 1586 Znać go mógł na przykład z edycji: Vergilius, Opera, ed. N. E. Lemaire, Parisiis 1819, vol. 7, s. 401 Przygotowując odpis pod koniec 1818 lub na początku 1819 roku, mógł korzystać już z tego wydani: (osobiście lub za czyimś pośrednictwem). Trudno określić, jaką wcześniejszą edycją mógłby się posłużyć ponieważ w przeważającej większości używanych ówcześnie wydań Wergiliusza utworu „Gallusa” wśróc testimoniów nie ma.

${ }^{81}$ Nie udalo mi się zidentyfikować autora ani zlokalizować cytatu mimo intensywnych poszukiwań w dzielach zebranych klasyków francuskich, zwłaszcza w:

A. Bertin, Oeuvres complètes..., Paris 1824;

C. de Chênedollé, Études poétiques..., Paris 1822;

A. Chénier, Oeuvres poétiques..., vol. 1-2, Paris 1878-1879;

P. D. (Écouchard) Le Brun, Oetures..., vol. 1-4, Paris 1811;

G. Legouvé, Oeuvres complètes..., vol. 1-3, Paris 1826-1827; tu m.in. L'Ènëide sauvée, poème en cinq chant: (vol. 3, 1827);

C.-H. Millevoye, Oetures complètes..., vol. 1-4, Paris 1827; tu m.in. Les derniers moments de Virgile (Elégies II 9, vol. 2); Les Bucoliques de Virgile (vol. 3); 
Zamykając krytykę Eneidy, autor podkreśla debiutancki charakter recenzji (chociaż, dodajmy: sześćdziesięcioletniego już autora), a wlasne uczucia przy tej okazji zestawia zręcznie $z$ fragmentem utworu Katullusa (c. 65, 19-24). Przekład świadczy o indywidualnym podejściu do klasyki. Katullus, odpowiadając - jak wolno przypuszczać — na monit przyjaciela o zaległy przekład poetycki, buduje homeryckie porównanie: spłoszona dziewczyna strąca na ziemię zapomniane w fałdach szaty jabłko od ukochanego. Obraz ten służy zaprzeczeniu: poeta rzymski, choć przeżył świeżo stratę brata, o dawnym zobowiązaniu pamięta. Wedykowski w tlumaczeniu (s. 43) obdarza wrażliwością emocjonalną nie tyle dziewczynę, co męskiego bohatera wiersza:

Jak oblubieniec przyszły, gdy ukradkiem

Zerwane jabłko nieznacznie uwinie,

To się gdy wymknie nadobnej dziewczynie

I z kolan spadnie na ziemię przypadkiem,

Matka nadchodzi, słyszy loskot $z$ dala,

Jabłko się toczy tu, ówdzie na strony,

Jemu błąd staje w oczach niecofniony

I cały wielkim wstydem się zapala.

Zasługi Katulla, powtórzone za autorem podręcznika Historia nauk wyzwolonych Juvenelem de Carlancas, i pochwała powyższego porównania ,autora z młodzieńcem, jabłka z pismem, matki z publicznością" kończą całość.

Trzeba podkreślić, że Wedykowski nigdzie nie powołuje się na recenzję Ludwika Osińskiego, i nie jesteśmy w stanie stwierdzić, czy ją znał. Ignorancja krytyka względem czasopism „uczonych” wydaje się nie do pomyślenia, raczej można przypuszczać, że zamanifestowal tak własne ambicje, które werbalnie deprecjonował. W każdym razie widać wyraźnie, ze sześciokrotnie mniej liczne uwagi Osińskiego bywają powierzchowniejsze, chociaż retorycznie doskonalsze. Niedostatki literackie komentarza Wedykowski rekompensuje niewątpliwą cierpliwością i wnikliwością, odważając się — powtórzmy z uznaniem — iść czasem wbrew Wergiliuszowi.

Wedykowski zawarł w szczuplejszej rezenzji fragment, który potwierdzalby omawianą wyżej wiadomość Czackiego o „spaleniu” jego prób przekładowych ${ }^{82}$, udzieloną listownie Molskiemu:

C.-H. Millevoye, Oetures..., éd. P. L. Jacob, vol. 1-3, Paris 1880; tu w t. 3 również Le chant de Virgile sur la naissance du Roi de Rome (ku czci syna Napoleona);

É. D. Desforges de Parny, Oetures complètes, Bruxelles 1830;

J. J. Lefranc de Pompignan, Oeuvres..., vol. 1-6, Paris 1784; tu m.in. przekład Georgik i VI księgi Encidy (vol. 4);

J. B. Rousseau, Oetures, vol. 1-5, Londres 1753;

P. Vergilius Maro, Aeneis... - L'Ėnéide, trad. par J. Delille, vol. 1-4, Paris 1804;

P. Vergilius Maro, Oetures..., trad. ... avec des remarques par M. l'abbé Desfontaines, vol. 1-2, Lyon 1801. ${ }^{82}$ Jeśli wierzyć wzmiankowanemu wcześniej rywalowi rektora szkól lubelskich, impulsem do tłumaczenia Eneidy „z oryginału” była praca Stanisława Staszica nad tłumaczeniem Homera p r o z ą (zob. list do J. I. Przy- 
Recenzent przełożył był dawniej trzy pierwsze księgi Wirgiliusza Eneidy, będąc profesorem wymowy w szkolach publicznych; ustąpił jednakże przekładu chwały imć pp. Molskiemu, Dmochowskiemu i Przybylskiemu, a ile w podeszłym już wieku, zgadza się z Marcjaliszem:

Vos vero mei ne festinate libelli,

Si post fata venit gloria, non propero ${ }^{83}$.

W rękopisie obszerniejszym, piśmie przeznaczonym intencjonalnie dla szerszej grup! odbiorców niż słuchacze zgromadzeni na posiedzeniu TPN w Lublinie, Wedykowski pomi. nął tę wiadomość, jako widocznie zbyt mało istotną czy za osobistą.

Nie wiemy, czy Franciszek Salezy Dmochowski, wydawca pism ojca, zapoznał się z prac: Wedykowskiego. Możemy jednak stwierdzić, że spośród miejsc poprawionych w wydani z 1830 roku tylko siedem dotyczy omawianych przez recenzenta, w tym zaledwie trz) odpowiadają dokładnie jego postulatom. W nowym wydaniu samobójcy „skrócili” zamias („rzucili”) życie własnymi rękoma (Dm. VI 448). Turnus „Szalony, drży do broni”, a niє „bronią rzęzi” (Dm. VII 471). „Prawiący” wcześniej Eneasz, ku któremu „usta zwrócil ciekawi”, zniknął zaś na rzecz obrazu:

Umilkło zgromadzenie, każdy słuch natęża,

Wtem taki głos wychodzi z ust zacnego męża (...) [Dm. II 1-2].

Drobiazgowa praca Wedykowskiego pozostała więc głosem niemal samotnym i nieskutecznym (podobnie jak Ludwika Osińskiego) - boć przecie nawet trzy ostatnie księgi. zastąpione przekładem Dmochowskiego-syna i Franciszka Kowalskiego — nie były owocem trudu lubelskiego arystarcha.

Literacka epoka późnego klasycyzmu polskiego bywa też określana mianem preromantyzmu. Rodzi się refleksja, że omówione fakty potwierdzają słuszność tej drugiej nazwy, bliższej sprawom irracjonalnym i ciemnym niż oświeconej klarowności świata. Widzieliśmy przecież „siłę fatalną” Franciszka Ksawerego Dmochowskiego! Jego Iliada pokonała Ignacego Nagurczewskiego, Eneida zaś - jako „powracająca fala, po prospekcie Molskiego - Seweryna Wedykowskiego. Zarazem ową „silą fatalną” promieniował sam „nasz przyjaciel Maro”: nie

bylskiego z Lublina, 16 III 1800, rps BJ 148, t. 4, k. 401v). Jednak znany dziś przekład Iliady Staszica (Warszawa 1815) dokonany został nierymowanym wierszem miarowym, którego zasady tłumacz szczegółowo objaśnial we wstępie. Wcześniej Staszic istotnie tłumaczył prozą poemat Louisa Racine Religia i Poema o zapadnieniu Lizbony Woltera (wyd. Warszawa 1779).

${ }^{83}$ Rps AGAD ApP 242, s. 266. Epigram Marcjalisa (V 10, w. 11-12) brzmi w przekładzie polskim:

Więc się, moje książeczki - chociaż czas ucieka -

Nie spieszcie! Jeśli slawę daje śmierć — poczekam.

(Marcjalis, Epigramy, tt. S. Kołodziejczyk, Warszawa 1985, s. 82). 
poradził mu (jeśli próbował...) Marcin Molski, zwątpił weń Franciszek Wężyk, osłabił pewność siebie Kajetana Koźmiana. Pokonał też i samego Dmochowskiego. Konwencje epoki nie daly trafić we właściwym czasie do rąk tłumacza Iliady krytycznej recenzji, autorstwa najtragiczniejszej postaci w tym kręgu, Józefa Sygierta. Los zrządził, że i przypomniana dziś, a wówczas najobszerniejsza recenzja Eneidy (choć daremna) trwała do naszych dni nieznana i niewykorzystana.

Prawda o poezji, krytyce i twórcach - do których już od czasów oświecenia zaliczano i tłumaczy - leży najpewniej gdzieś między „przekleństwem Dydony” i „sztuką rymotwórzzą", między mrocznym natchnieniem i słonecznym rzemiosłem.

Z urojenia bierze się poezja -

— stwierdza Milosz w cytowanym wierszu, a przecież:

...słodko jest myśleć, że byłem kompanem w wyprawie, która nigdy nie ustaje, choć mijają wieki. (...)

Bratersko wspieramy się wzajemnie, zapominając uraz, tłumacząc jedni drugich na inne języki, zaiste, członkowie wędrującej załogi ${ }^{84}$.

Zaiste, autorem takiego Sprawozdania mógłby być Sygiert lub Wedykowski.

${ }^{34}$ Cz. Miłosz, Sprawozdanie, op. cit., s. 5, 6, 7.

Pragnę serdecznie podziękować P.T. Pracownikom ponad sześćdziesięciu bibliotek i archiwów krajowych, uczestniczącym w kwerendzie na rzecz niniejszej pracy, a zwlaszcza Archiwum Uniwersytetu Jagiellońskiego, Archiwum Diecezjalnego w Lublinie, Biblioteki Jagiellońskiej i Biblioteki Zgromadzenia Księży Misjonarzy w Krakowie. Ważne tropy i inspirujące wskazówki zawdzięczam prof. Elżbiecie Aleksandrowskiej i doc. Jerzemu Snopkowi. Osobną wdzięczność winienem dr Izabelli Zatorskiej za uczynne poszukiwania czterowersowej igty we francuskim klasycznym stogu... 


\section{Aneks}

\section{Przemowa przy złożeniu do grobu ciała ś[więtej] p [amięci] W. Imci Księdza Franciszka Zabłockiego, proboszcza końskowolskiego przez ks. Seweryna Wedykowskiego p[roboszcza] m[arkuszowskiego, $\mathbf{k}$ [anonika] $\mathbf{k}$ [atedralnego] 1 [ubelskiego] miana dnia 12 września 1821 roku w Końskowoli}

\section{Opracował Jacek Wójcicki}

Laudavi magis mortu[os] quam viventes. Eccl. IV [2 Chwaliłem bardziej zmarłych jak żyjących. Słowa Eklezy[jasty] Pań[skiego

Ta jest między zmarłymi a żyjącymi w zasłudze pochwał różnica, iż czlowiek w trumnie wiemy, w czym był dla spółeczności użyteczny lub szkodliwy. Przeciwnie za życia: siłaż razy piękne młodości postępki splamiły wieku męskiego lub starego wady?

Dzień zaś śmierci, uwieńczając statecznością życia cnoty, dowodzi, że nie przestał by، dobrym, kto nim być zaczął.

Takim był ów mąż, którego śmiertelne zwłoki w tej tu trumnie złożone widziemy, mając być wkrótce ręką czasu zasklepione w ziemi, dotąd, póki trąba anioła nie powoła go z nam po skończonym tym życiu śmiertelnym na dzień ostatni, światu i ludziom niemylny.

Nic by mi nie pozostało mówić nad to, co wymowne usta w dniu dzisiejszym każącego ${ }^{8:}$ na pochwałę ś[więtej] p[amięci] W. Imć Ks[iędza] Franciszka Zabłockiego p[roboszcza] $\mathrm{k}$ [ońskowolskiego] wyraziły, gdyby dawna moja z zmarłym teraz przyjaźń i związek w Towarzystwie Przyjaciół Nauk w województwie lubelskim nie zniewoliły mię oddać hołć cnotom i przymiotom jego przynależny.

Jakoż, pominąwszy tego znakomitego męża w literaturze dla kraju przysługi: owe zabawne dzieła teatralne, w których geniusz jego wygórował, a które są i będą dobrze myślących i z gustem zabawą i rozkoszą; ów przekład z francuskiego dzieła w pięciu tomach Saint-Reala $^{86}$, gdzie przyjemnych obrazów piękność czuć się na każdej karcie daje każdemu miłośnikowi starożytności, zawód jego był stanąć u styru wysokiej magistratury, jaką kiedyś była Komisja Edukacyjna, przy której lat kilkanaście z chwałą przyjęte pełnił obowiązki ${ }^{87}$.

Z odmianą losu ojczyzny, nie mogąc przenieść na swym sercu po stracie jej żalu, w obcym więc kraju pozbyć się go usiłował. Udał się przeto do Rzymu ${ }^{88}$, gdzie poznawszy próżność świata

\footnotetext{
${ }^{85}$ WMci Ks. Pieńkowski proboszcz kurowski mial kazanie [przyp. autora].

${ }^{86}$ Zob. [C. V. de] Saint-Réal, Dzieła... przekladania Franciszka Zablockiego, t. 1-5, Warszawa, P. Dufour, 1778 [t. 1-3]-1779 [t. 4-5].

${ }^{87}$ Zablocki byl protokolistą Komisji Edukacji Narodowej od 1774 roku.

${ }^{88} \mathrm{~W}$ połowie 1795 roku, częściowo niewątpliwie z obawy przed represjami za udział w insurekcji kościuszkowskiej.
} 
tego, powziąl do stanu duchownego powołanie i w tej stolicy Kościoła prawowiernego sposobił się w naukach duchownych, i tamże poświęcony został, przechodząc stopniami na kapłana.

Powróciwszy do kraju ${ }^{89}$, od lat młodych zaszczycony względami JO Książąt Czartoryskich, których dom słynie zawsze jedynym dla uczonych rodaków przytułkiem, przyjął tutejszej parafii obowiązki ${ }^{90}$.

Czuł dobrze ich ważność, gdy pomimo chlubne zasług swoich zaszczyty, powszechną z nauk wziętość i wiek swój sędziwy, jak ów Fénelon lub Massilon, nie uchylał się od posługi ewangelicznej dla parafii końskowolskiej, często dojeżdżając do chorych w owych momentach okropnych, gdzie prawowierni w osobie pasterza anioła widzieć się zdają. Nauczał przy tym owieczki swoje po większej części sam przez siebie i budował własnym przykładem, a tak czułym będąc o ich duchowne dobro, wspierał cierpiącą ludzkość bez chluby i próżnego o niej gadania.

Był albowiem człowiekiem poczciwym, skromnym, obyczajów łagodnych i umysłu jednostajnego. W zdaniach i postępkach swoich filozof wyjęty do ambicji. Dusza jego wspaniała nie zwykła się byla czołgać do wypraszania dobrodziejstw lub zaszczytów, na które sprawiedliwie zasłużył. Czczony był od przyjaciól; a któryż zlośliwy człowiek ma przyjaciól prawdziwych! Słowem, dobry był obywatel, dobry kapłan, dobry pasterz, jakiego tylko diecezja lubelska mogła życzyć sobie.

Te to kwiaty pochwał dorywczo z życia jego zebrane, które tu przy tym zostawiam grobie, bodajby świeże długo na ziemi były, jak ów chwały wieniec, który, przeniósłszy się z tego życia do wiecznego, nie wątpię, że z rąk stwórcy odebrał.

Chrześcijanie! Przekonani, że to życie na ziemi doczesne krótkąjest podróżą, za cóż nie poglądacie na cel wyższy przeznaczenia swego: złączenia się z Bogiem, mając przed sobą tyle śmierci obrazów, oto i ten jej przedmiot, na który z żalem patrzemy? Na próżno śmierć od siebie oddalamy, każdy moment ją do nas zbliża: mlodość niknie, lata prędko leca, jesteśmy podobni do wód, które wpadają w morze, nie powracając do swego źrzódła.

Inaczej czuł i myślał ś[więtej] p[amięci] Franciszek Zabłocki p[roboszcz] k[ońskowolski]. Już on od kilku lat, zdrowym jeszcze będąc, ostatnie woli swojej uczynił rozrządzenie, wierząc, że jest śmiertelnym, nie wiedzący dnia i godziny, a czując zbliżający się moment ostatni swego zgonu, starał się być opatrzonym ś[więtymi] sakramentami na drogę wieczności.

Takowa śmierć przed Bogiem jest chwalebna i szczęśliwą rokuje przyszłość. A jeżeli pozostały jeszcze jakowe jego ułomności, za które się teraz Bogu wypłaca, westchnijcież za nim do niebios, mówiąc: „Boże, niech mu Twa światłość przyświeca z świętymi Twymi, albowiem pełen jesteś milosierdzia! - Lux aeterna luceat ei cum sanctis suis in aeternum quia pius es".

${ }^{89} \mathrm{~W}$ roku 1797.

90 Od grudnia 1800 roku, po Grzegorzu Piramowiczu, w wieku niespelna 49 lat (ur. 2 I 1752); tu zmarł 10 IX 1821. Zob. Kalendaritum życia i twórczości; Aneks do Kalendarium, w: Teatr Franciszka Zabtockiego, opr. J. Pawłowiczowa, t. 5: W stronę teatru muzycznego, Wroclaw 1996, s. 327-431. 